Report No. BMI- 1685

UC-25 Metals, Ceramics, and Materials

(TID-4500, 32nd Ed.)

AEC Contract $W-7405-e n g-92$

CONSTITUTION OF THE SYSTEMS OF URANIUM AND CARBON WITH MOLYBDENUM, NIOBIUM, RHENIUM, TUNGSTEN, AND YTTRIUM

by

Walston Chubb

Donald L. Keller

August 11, 1964

BATTELLE MEMORIAL INSTITUTE

505 King Avenue

Columbus, Ohio 43201 


\section{DISCLAIMER}

This report was prepared as an account of work sponsored by an agency of the United States Government. Neither the United States Government nor any agency Thereof, nor any of their employees, makes any warranty, express or implied, or assumes any legal liability or responsibility for the accuracy, completeness, or usefulness of any information, apparatus, product, or process disclosed, or represents that its use would not infringe privately owned rights. Reference herein to any specific commercial product, process, or service by trade name, trademark, manufacturer, or otherwise does not necessarily constitute or imply its endorsement, recommendation, or favoring by the United States Government or any agency thereof. The views and opinions of authors expressed herein do not necessarily state or reflect those of the United States Government or any agency thereof. 


\section{DISCLAIMER}

Portions of this document may be illegible in electronic image products. Images are produced from the best available original document. 
ABSTRACT

INTRODUCTION

URANIUM-CARBON-MOLYBDENUM SYSTEM

Background

Crystallography

Experimental Results

Ternary Sections

URANIUM-CARBON-NIOBIUM SYSTEM .

Background

Crystallography.

Experimental Results

Ternary Sections

URANIUM-CARBON-RHENIUM SYSTEM

Background

Crystallography.

Experimental Results .

Ternary Section.

URANIUM-CARBON-TUNGSTEN SYSTEM .

Background

Crystallography.

Experimental Results

Ternary Section.

Background

Crystallography.

Experimental Results

Binary Constitutional Diagram .

URANIUM-CARBON-YTTRIUM SYSTEM

Experimental Results .

Ternary Section

ACKNOW LEDGMENT . 


\title{
CONSTITUTION OF THE SYSTEMS OF URANIUM AND CARBON WITH MOLYBDENUM, NIOBIUM, RHENIUM, TUNGSTEN, AND YTTRIUM
}

by

Walston Chubb and Donald L. Keller

\begin{abstract}
The uranium-carbon-molybdenum system was found to contain only one ternary phase, $U M \mathrm{MO}_{2}$, possessing a range of homogeneity from 46 to 50 a\% carbon. A pseudobinary tie line exists between UC and molybdenum below $1800 \mathrm{C}$. Between 1800 and $1900 \mathrm{C}, U \mathrm{C}$ and molybdenum react peritectically to form uranium liquid and $\mathrm{MMOC}_{2}$. Pseudobinary systems also exist between UMoC $\mathrm{C}_{2}$ and $U \mathrm{C}$, graphite, $\mathrm{Mo}_{2} \mathrm{C}$, and molybdenum. $\mathrm{Nb}_{2} \mathrm{C}$ and $\mathrm{NbC}$ in intimate contact with liquid uranium at $1540 \mathrm{C}$ contained less than 1 a/o uranium; the uranium contained no detectable niobium. The UC-NbC solid solution does not contain less than 49 a/o carbon at any composition containing more than 1 a/o uranium. The NbC corner of the $\mathrm{NbC-Nb}{ }_{2} \mathrm{C}$-uranium region lies near $45 \mathrm{a} / \mathrm{o}$ carbon, $54 \mathrm{a} / \mathrm{o}$ niobium, and less than 1 a/o uranium. The uranium-carbon-rhenium system contains a ternary phase, $U R e C_{2}$. Pseudobinary tie lines extend from UC to URe $e_{2}$, from UC to rhenium, and from URe $C_{2}$ to rhenium. Like in the uranium-carbon-molybdenum system, pseudobinary tie lines exist in the uranium-carbon-tungsten system at $1500 \mathrm{C}$ between UC and tungsten and between $U W C_{2}$ and all the phases in the system except uranium. At $1500 \mathrm{C}$, the yttrium-carbon system contains two intermediate phases, a peritectically formed face-centered-cubic phase, YC, containing about 40 a/o carbon and an equiaxed and presumably cubic dicarbide, $Y C_{2}$, which transforms to a tetragonal structure below $1500 \mathrm{C}$. A complete series of solid solutions exists between $U C$ and $Y C$ and, probably, between $U C_{2}$ and $Y C_{2}$. The UC-YC solid solution contains less than 50 a/o carbon at compositions containing as little as 8 a/o yttrium. Yttrium displaces uranium from the UC-YC solid solutions.
\end{abstract}

\section{INTRODUCTION}

As the development of a metal leads to the investigation of its binary phase relations with other elements, so the development of a compound such as uranium carbide leads to the development of its ternary phase relations with other elements. The constitution of the uranium-carbon systems with most of the more common metals of reactor construction were reviewed, on the basis of fragmentary information in the literature, in BMI-1441 (May 31, 1960). (1) The studies reported here represent an attempt to amplify, confirm, or amend the constitutional diagrams of some of the systems reported in BMI- 1441 .

(1) References at end. 
Background

The melting point of $\mathrm{Mo}_{3} \mathrm{C}_{2}(\mathrm{MoC})$ is about $2650 \mathrm{C.}(2)$

$\mathrm{Mo}_{2} \mathrm{C}$ decomposes peritectically on heating at about $2400 \mathrm{C}$. (2)

$\mathrm{UMoC}_{2}$ melts at about $2350 \mathrm{C.}$ (3) A eutectic exists between $\mathrm{UMOC}_{2}$ and carbon at $2200 \mathrm{C}$. A eutectic exists between $\mathrm{UMoC}_{2}, \mathrm{UC}_{2}$, and carbon at $2170 \mathrm{C}$.

An alloy of 43 a/o uranium, 43 a/o molybdenum, and 14 a/o carbon contained uranium monocarbide, molybdenum metal, and uranium metal. (4)

Alloys of uranium containing up to $44 \mathrm{a} / \mathrm{o}$ carbon and 6 a/o molybdenum or 38 a/o molybdenum and 5 a/o carbon contain uranium monocarbide in a matrix of molybdenum and uranium-molybdenum alloy. (5)

$\mathrm{UMoC}_{2}$ forms on the high-carbon side of the UC-molybdenum tie line. (6)

A compound having the approximate composition $\mathrm{U}_{2} \mathrm{Mo}_{5} \mathrm{C}_{3}$ has been reported. At $1500 \mathrm{C}$, pseudobinary tie lines extend between this phase and $\mathrm{UC}, \mathrm{UM}_{\circ} \mathrm{C}_{2}, \mathrm{Mo}_{2} \mathrm{C}$, and molybdenum. (7)

The various carbides formed in this system do not dissolve in one another to any appreciable extent. $(3,4,7,8)$

\section{Crystallography}

$\mathrm{Mo}_{3} \mathrm{C}_{2}(\mathrm{MoC})$ is face-centered cubic ( $\mathrm{NaCl}$ type) above about $1800 \mathrm{C}$, with $\mathrm{a}=4.27 \mathrm{~A}$. The compound is complex hexagonal below $1800 \mathrm{C}$, having four or more molecules per unit cell. Density is about 9 ger $\mathrm{cm}^{3} \cdot(9,10)$

$\mathrm{Mo}_{2} \mathrm{C}$ is hexagonal close-packed ( $\mathrm{W}_{2} \mathrm{C}$ type), having one molecule per unit cell, with $a=3.00$ and $c=4.73 \mathrm{~A}$. Density is $9.3 \mathrm{~g}$ per $\mathrm{cm}^{3}$.

$\mathrm{UMoC}_{2}$ is orthorhombic ( $\mathrm{UCrC}_{2}$ type), having four molecules per unit cell, with $\mathrm{a}=5.61, \mathrm{~b}=3.22$, and $\mathrm{c}=10.95 \mathrm{~A}$. Density is $12.0 \mathrm{~g}$ per $\mathrm{cm}^{3} .(11)$

\section{Experimental Results}

The alloys shown in Table 1 were prepared by arc melting using the elemental materials. No weight losses were observed after each composition had been melted and turned over five times, so the final compositions were assumed to be the same as the nominal compositions. The cast alloys, weighing $50 \mathrm{~g}$, were broken into several pieces, and the phases present were identified by metallographic methods, hardness 
measurements, and X-ray diffraction techniques. Many of the alloys were annealid for various times at various temperatures and re-examined. The results of these examinations are summarized in Table 1.

TABLE 1. PHASES FOUND IN URANIUM-CARBON-MOLYBDENUM ALLOYS

\begin{tabular}{|c|c|c|c|c|c|c|}
\hline \multirow[b]{3}{*}{ Alloy } & \multirow{2}{*}{\multicolumn{3}{|c|}{$\begin{array}{c}\begin{array}{c}\text { Nominal Composition } \\
\mathrm{a} / \mathrm{o}\end{array} \\
\end{array}$}} & \multicolumn{3}{|c|}{$\begin{array}{l}\text { Phases Identified by Metallographic } \\
\text { and X-Ray Methods(a) }\end{array}$} \\
\hline & & & & \multirow[b]{2}{*}{ As Cast } & \multirow{2}{*}{$\begin{array}{c}\text { Annealed } 3 \mathrm{Hr} \\
\text { at } 1500 \mathrm{C}\end{array}$} & \multirow{2}{*}{$\begin{array}{c}\text { Annealed } 1 / 2 \mathrm{Hr} \\
\text { at } 190 \mathrm{C} \mathrm{C}\end{array}$} \\
\hline & $\mathrm{U}$ & $\mathrm{C}$ & Mo & & & \\
\hline$M-1$ & 43 & 14 & 43 & UC, Mo, (U, Mo) alloy & -- & - \\
\hline$M-2$ & 35 & 15 & 50 & $\mathrm{UC}, \mathrm{Mo},(\mathrm{U}, \mathrm{Mo})$ alloy, $\mathrm{UMoC}_{2}$ & UC, Mo, (U, Mo) alloy & -- \\
\hline$M-3$ & 30 & 20 & 50 & Mo, UC, $\mathrm{UMoC}_{2}$ & UC, Mo, (U, Mo) alloy & $-\cdots$ \\
\hline$M-4$ & 25 & 25 & 50 & $\mathrm{UMOC}_{2}, \mathrm{UC}, \mathrm{Mo}$ & $\mathrm{UC}, \mathrm{Mo}, \mathrm{UMoC}_{2}$ & $\mathrm{UMOC}_{2}, \mathrm{Mo}, \mathrm{UC}^{(\mathrm{b})}$ \\
\hline$M-5$ & 20 & 30 & 50 & $\mathrm{UMoC}_{2}^{2}, \mathrm{Mo}, \mathrm{UC}$ & $\mathrm{UMOC}_{2}, \mathrm{Mo}, \mathrm{UC}$ & $\mathrm{UMOC}_{2}, \mathrm{Mo}, \mathrm{UC}^{(\mathrm{b})}$ \\
\hline$M-6$ & 33 & 33 & $33(c)$ & $\mathrm{UMOC}_{2}$, UC, Mo & UC, Mo & $\mathrm{UMOC}_{2}, \mathrm{UC}^{(\mathrm{b})}, \mathrm{Mo}$ \\
\hline$M-7$ & 15 & 35 & 50 & $\mathrm{UMoC}_{2}^{2}, \mathrm{Mo}_{2} \mathrm{C}, \mathrm{Mo}$ & $\mathrm{UMoC}_{2}, \mathrm{Mo}, \mathrm{Mo}_{2} \mathrm{C}$ & $\mathrm{UMoC}_{2}, \mathrm{Mo}, \mathrm{Mo}_{2} \mathrm{C}$ \\
\hline$M-8$ & 12 & 38 & 50 & $\mathrm{Mo}_{2} \mathrm{C}, \mathrm{UMoC}_{2}$ & - & (2) \\
\hline$M-9$ & 20 & 40 & 40 & $\mathrm{UMOC}_{2}$, Mo & -- & $\mathrm{UMoC}_{2}, \mathrm{Mo}$ \\
\hline$M-10$ & 29 & 42 & 29 & $\mathrm{UMoC}_{2}^{2}$, UC, Mo & $\mathrm{UMoC}_{2}, \mathrm{UC}, \mathrm{Mo}^{(\mathrm{d})}$ & $\mathrm{UMOC}_{2}, \mathrm{UC}, \mathrm{Mo}$ \\
\hline$M-11$ & 27 & $46^{(c)}$ & 27 & $\mathrm{UMoC}_{2}, \mathrm{UC}, \mathrm{Mo}$ & $\quad-$ & $\mathrm{UMOC}_{2}$ \\
\hline$M-12$ & 43 & 49 & 8 & $\mathrm{UC}, \mathrm{UMoC}_{2}$ & -- & -- \\
\hline$M-13$ & 25 & 50 & 25 & $\mathrm{UMoC}_{2}$ & $\mathrm{UMoC}_{2}$ & -- \\
\hline$M-14$ & 21 & 57 & 22 & $\mathrm{UMOC}_{2}, \mathrm{C}$ & - & 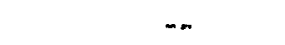 \\
\hline$M-15$ & 20 & 60 & 20 & $\mathrm{UMoC}_{2}, \mathrm{C}$ & -- & $\infty$ \\
\hline
\end{tabular}

(a) Phases are listed in order of decreasing volume.

(b) UC apparently was part of a liquid phase at $1900 \mathrm{C}$.

(c) Spot-check analyses showed nominal compositions to be correct within $1 \mathrm{a} / \mathrm{o}$.

(d) Same result was achieved after $8 \mathrm{hr}$ at $1500 \mathrm{C}$.

The cast structure of Alloy M-1 (43 a/o uranium-14 a/o carbon- 43 a/o molyodenum) is shown in Figure 1. This structure shows molybdenum dendrites in a UC: matrix with an intergranular residue of (U, Mo) alloy. It suggests the existence of a triangular, three-phase field having corners at UC, molybdenum, and (U, Mo) allo\%. (4)

The annealed structures of Alloys $M-2$ and $M-3$ in Table 1 showed the same three phases as Alloy $\mathrm{M}-1$, but the cast structures of these two alloys showed appreciable quantities of a phase which looked like $\mathrm{UMOC}_{2}$ and which was apparently a carbondeficient solid solution based on $\mathrm{UMOC}_{2}$ containing as little as 46 a/o carbon. The Xray patterns of $\mathrm{UMOC}_{2}$ containing 46 a/o carbon and of $\mathrm{UMOC}_{2}$ containing 50 a/o carbon are distinctly different, as shown in Figure 2. The X-ray pattern of the former was initially assumed to be as sociated with the phase $\mathrm{U}_{2} \mathrm{Mo}_{5} \mathrm{C}_{3}$ reported previously(7), but it was not found at this composition, and it was subsequently obtained on the essentially single-phase alloy containing 27 a/o uranium, 46 a/o carbon, and 27 a/o molybdenum. Typical microstructures of $\mathrm{UMoC}_{2}$ containing 46 and 50 a/o carbon are shown in Figure 3.

The as-cast structure of the Alloy $\mathrm{M}-3$ in Table 1 is shown in Figure 4. The: appearance of primary crystals of $\mathrm{UMOC}_{2}$ in cast alloys of such low carbon contenits 


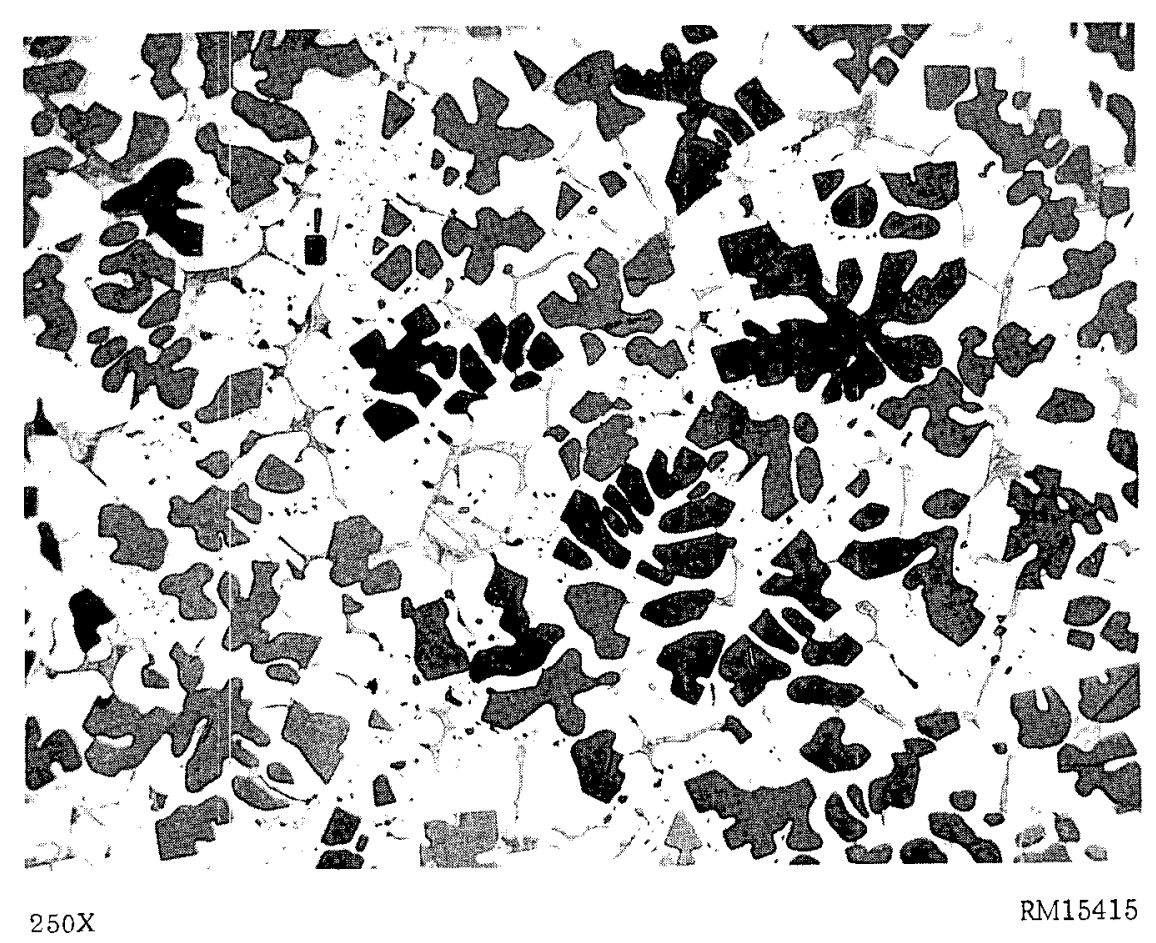

FIGURE 1. AS-CAST STRUCTURE OF 43 a /O URANIUM-14 a $/ 0$ CARBON-43 a $/ 0$ MOLYBDENUM ALLOY

Dark gray dendrites are molybdenum, light gray regions are UC, and intergranular phase is (U, Mo) alloy.

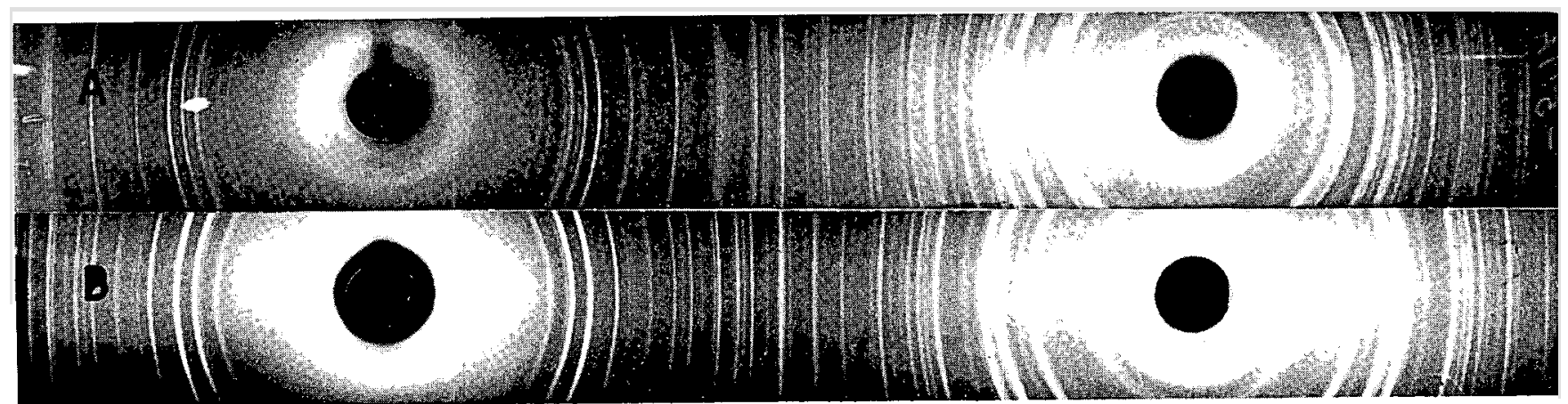

FIGURE 2. X-RAY DIFFRACTION PATTERNS OF URANIUM-CARBON-MOLYBDENUM ALLOYS
A: 27 a /o uranium -46 a /o carbon -27 a $/ 0$ molybdenum alloy annealed $1 / 2 \mathrm{hr}$ at $1900 \mathrm{C}$, showing unidentified structure plus a small amount of UC (Alloy M-11).
B: 25 a $/ 0$ uranium -50 a $/ 0$ carbon -25 a $/ 0$ molybdenum alloy annealed $3 \mathrm{hr}$ at $1500 \mathrm{C}$, showing single-phase $\mathrm{UMOC}_{2}$. 


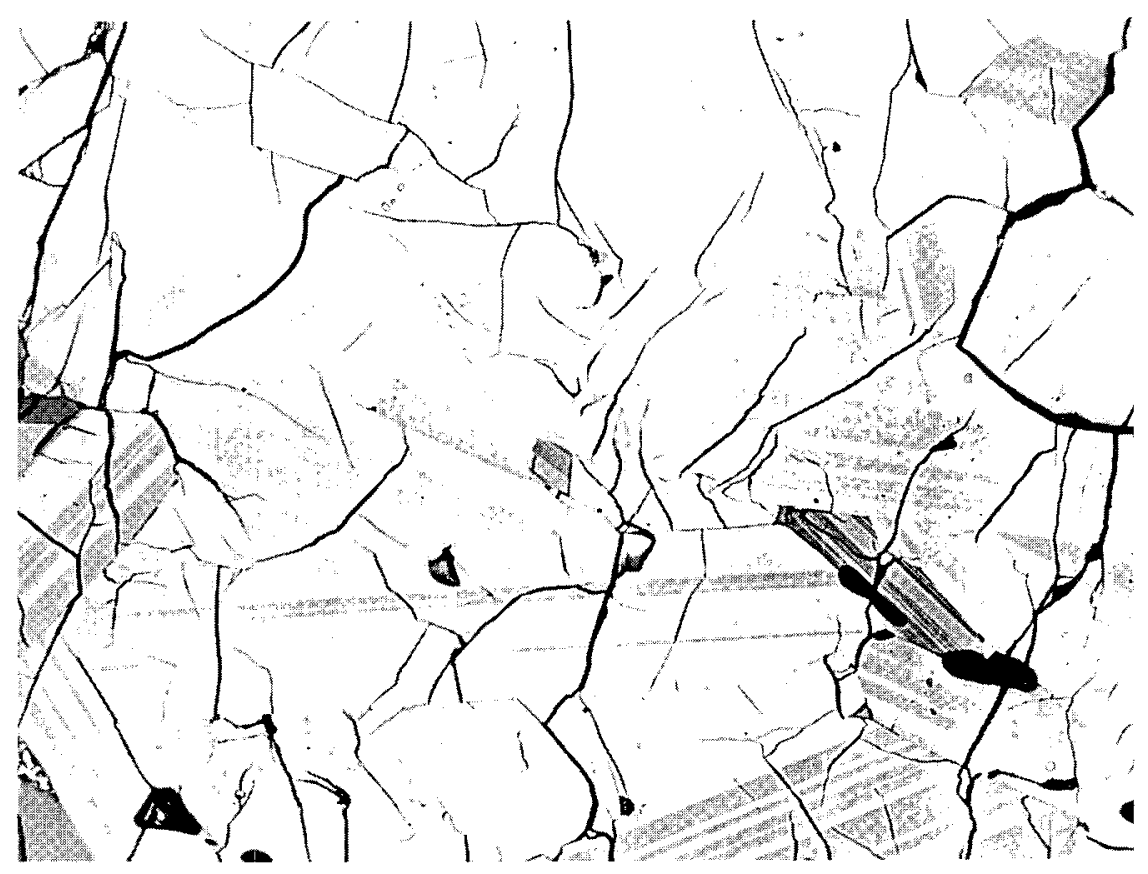

$250 \mathrm{X}$

RM31193

a. 46 a /o Carbon, Annealed $1900 \mathrm{C}$

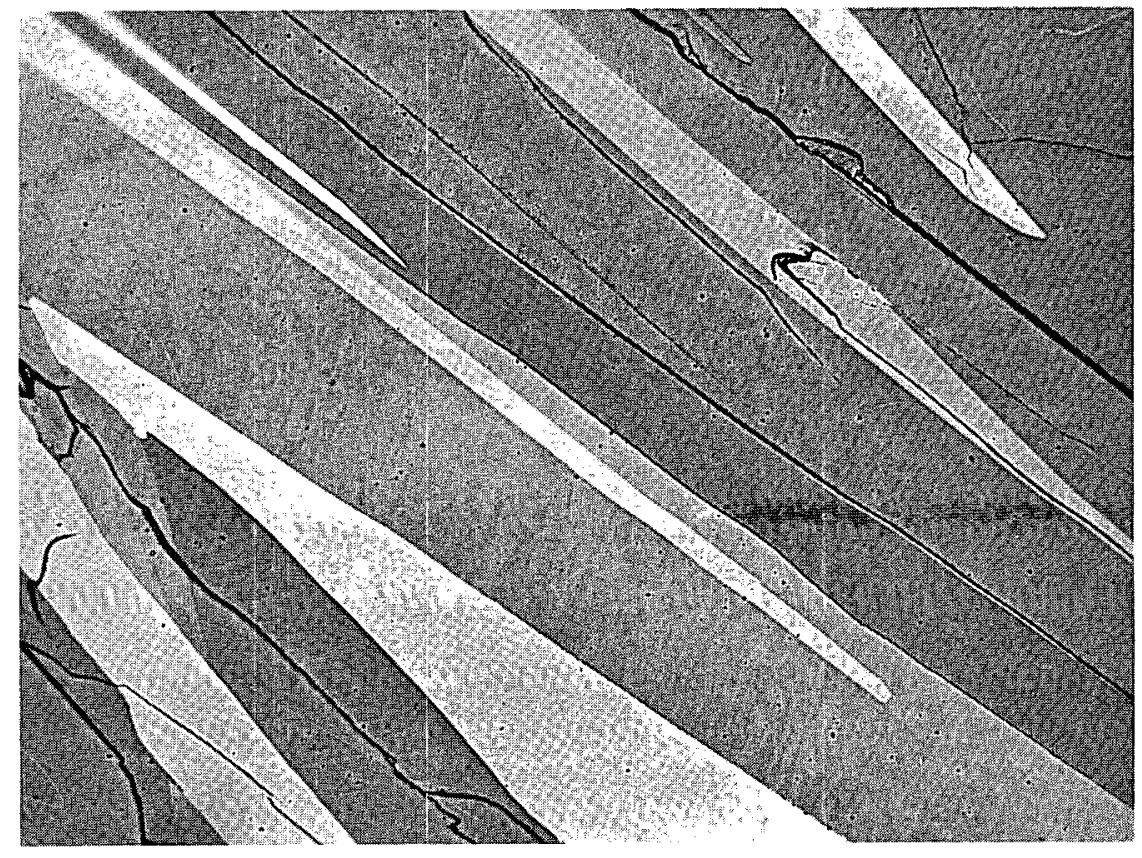

b. 50 a /o Carbon, As Cast

FIGURE 3. TYPICAL STRUCTURES OF UMoC 2 AT 46 a $/$ CARBON AND 50 a /O CARBON

Striations are accentuated by Murikami's regeant. 
is indicative of a high-melting phase which forms directly from a liquid of low carbon content at some high temperature. The disappearance of $\mathrm{UMoC}_{2}$ on annealing at $1500 \mathrm{C}$ is indicative of a peritectic reaction of the type: $\mathrm{UMOC}_{2}+\mathrm{U}$ (liquid) $=2 \mathrm{UC}+$ $\mathrm{Mo}$, at some temperature above $1500 \mathrm{C}$.

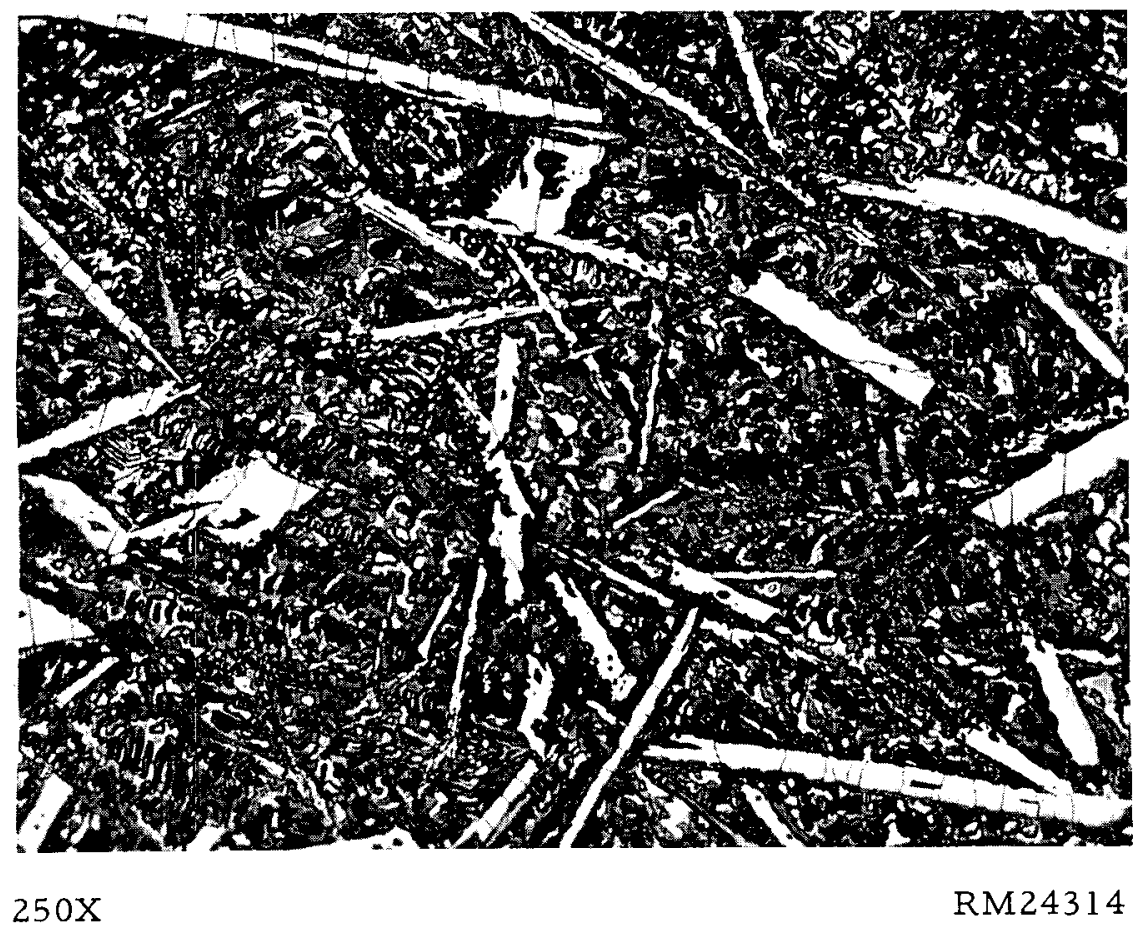

FIGURE 4. AS-CAST STRUCTURE OF 30 a/o URANIUM-20 a/o CARBON50 a/o MOLYBDENUM ALLOY

White needles are $\mathrm{UMoC}_{2}$, gray and black matrix contains UC and molybdenum.

Alloy M-4 (25 a/o uranium-25 a/o carbon-50 a/o molybdenum) and Alloy M-6 ( 33 a/o uranium-33 a/o carbon-33 a/o molybdenum) fall very nearly on a line from UC to molybdenum. The cast structures of these alloys were similar to that of alloy $\mathrm{M}-3$ (shown in Figure 4) except that the amounts of primary $\mathrm{UMoC}_{2}$ needles were much greater relative to the amounts of $U C$ and molybdenum. When these two alloys were annealed at $1500 \mathrm{C}$, the resultant structures contained virtually no $\mathrm{UMoC}_{2}$. The structure of Alloy M-6 treated at $1500 \mathrm{C}$ is shown in Figure 5. This structure shows the existence of a pseudobinary tie line from UC to molybdenum at $1500 \mathrm{C}$ in agreement with the structure shown in Figure 1. However, when these same alloys were heated for $1 / 2 \mathrm{hr}$ at $1900 \mathrm{C}$, the structure changed in a most drastic manner, as shown in Figure 6. Both samples showed signs of having been partly molten at $1900 \mathrm{C}$. With reference to Figure 6, the large, twinned crystals are $\mathrm{UMoC}_{2}$, which was present as a solid at $1900 \mathrm{C}$; the irregular, white globules around the edges of the $\mathrm{UMoC}_{2}$ are molybdenum, at least part of which was present as a solid at $1900 \mathrm{C}$; the remaining gray and white matrix material is now a mixture of UC and molybdenum metal which was a uranium-base liquid at $1900 \mathrm{C}$. Figures 5 and 6 establish the existence of a peritectic reaction $\left(\mathrm{UMoC}_{2}+\right.$ liquid $=\mathrm{UC}+\mathrm{Mo}$ ) at a temperature between 1500 and $1900 \mathrm{C}$. A further heat treatment of the Alloy M-6 at $1800 \mathrm{C}$ produced a UC-plus-molybdenum structure similar to that of Figure 5, so the peritectic temperature must be between 1800 and $1900 \mathrm{C}$. 


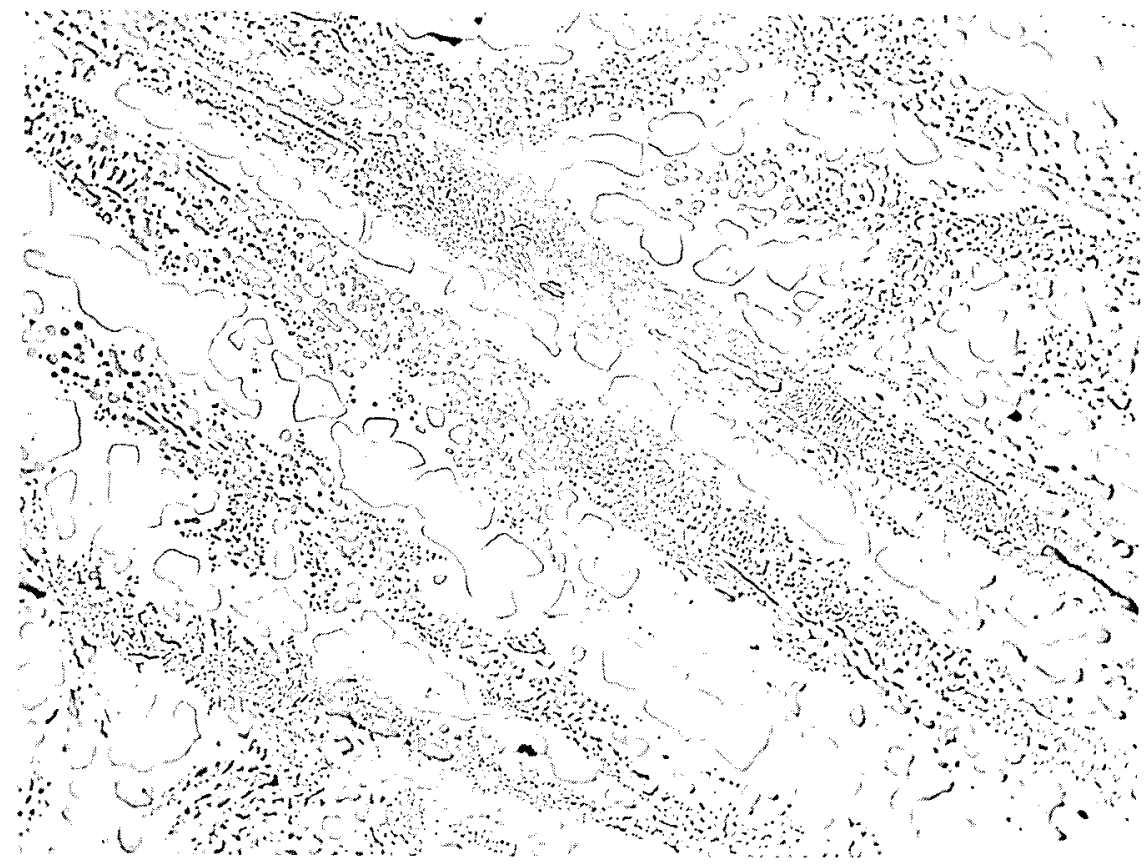

$250 \mathrm{X}$

RM27355

As Polished

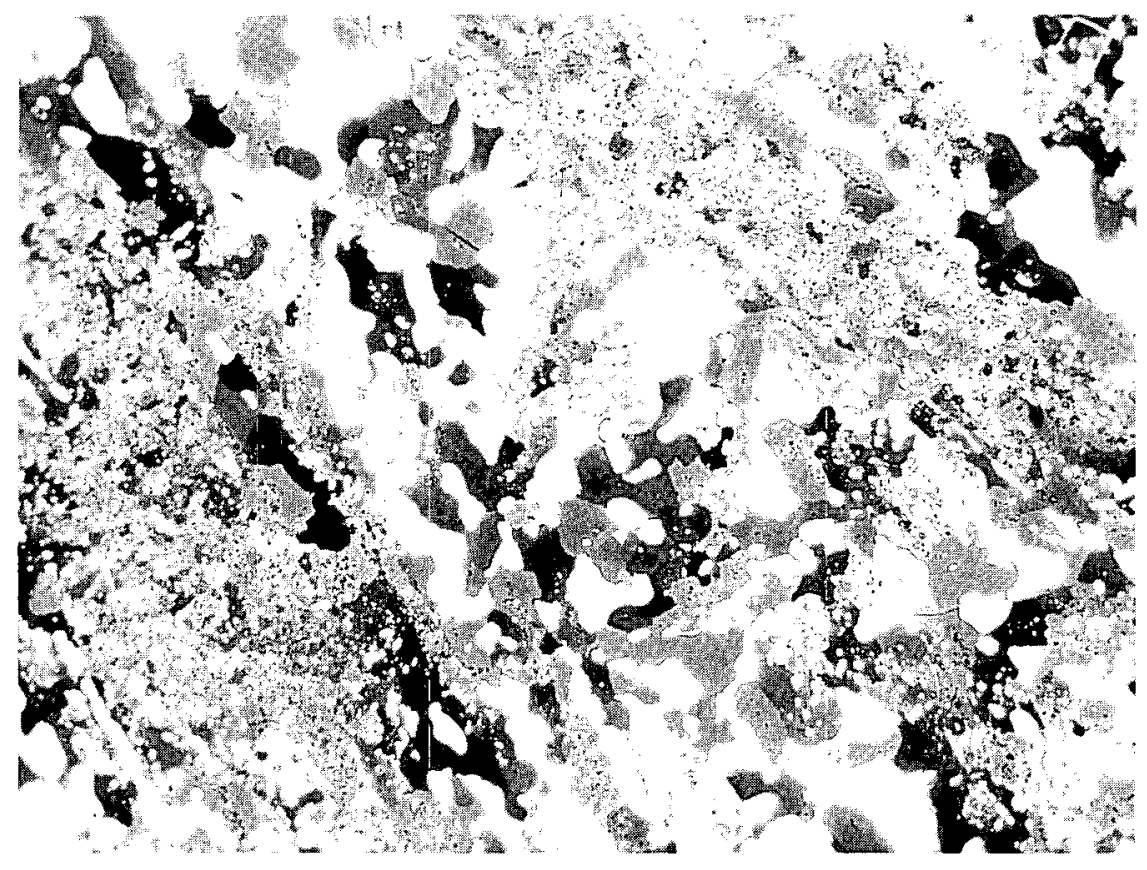
$250 \mathrm{X}$

RM27353

Etched

FIGURE 5. STRUCTURE OF 33 a /o URANIUM-33 a /o CARBON-33 a /o MOLYBDENUM ALLOY, ANNEALED 3 HR AT $1500 \mathrm{C}$

White phase is molybdenum. Matrix showing grain structure when etched is UC. 
Alloy M-5 (20 a/o uranium-30 a/o carbon-50 a/o molybdenum) had a cast structure similar to that shown in Figure 4. This alloy, which is at the composition of the phase $\mathrm{U}_{2} \mathrm{Mo}_{5} \mathrm{C}_{3}$ reported in the literature(7), was found to contain three phases both as cast and as heat treated at 1500, 1800, and $1900 \mathrm{C}$. The only change which occurred during these heat treatments was that the phases tendened to coarsen and spheroidize. The structure produced in this alloy at $1900 \mathrm{C}$ is shown in Figure 7 . This structure consists mainly of two phases: the gray phase showing longitudinal lines is identified as $\mathrm{UMoC}_{2}$; the white phase is identified as molybdenum. The remainder represents liquid which decomposed into UC and molybdenum on cooling. The presence of such a small amount of liquid shows that this composition is near a pseudobinary tie line from $\mathrm{UMoC}_{2}$ to molybdenum.

Alloys M-7, M-8, and M-9 (15 a/o uranium-35 a/o carbon-50 a/o molybdenum, 12 a/o uranium-38 a/o carbon-50 a/o molybdenum, and 20 a/o uranium-40 a/o carbon$40 \mathrm{a} / 0$ molybdenum) confirm the above tie and establish the existence of a three-phase field with corners at $\mathrm{UMoC}_{2}, \mathrm{Mo}_{2} \mathrm{C}$, and molybdenum.

The structure of Alloy $\mathrm{M}-8$ is shown in Figure 8. This structure shows only two phases, $\mathrm{UMoC}_{2}$ and $\mathrm{Mo}_{2} \mathrm{C}$, and is apparently near a pseudobinary eutectic. Based on the amount of excess $\mathrm{MO}_{2} \mathrm{C}$ in this structure, the pseudobinary eutectic must be near 47 a/o molybdenum, 40 a/o carbon, and 13 a/o uranium.

Alloys M-10, M-11, and M-12 (29 a/o uranium-42 a/o carbon-29a/o molybdenum, 27 a/o uranium-46 a/o carbon- 27 a/o molybdenum, and 43 a/o uranium- 49 a/o carbon$8 \mathrm{a} / 0$ molybdenum) establish the existence of a three-phase field with cornersat $\mathrm{UMoC}_{2}$, molybdenum, and UC at temperatures up to the peritectic temperature, where the UCmolybdenum tie line disappears. The structures of Alloys $M-11$ and $M-13$ are shown in Figure 3. Changes in the relative amounts of $U C$ and molybdenum in the structures of Alloys $M-10$ and $M-11$ as a function of temperature of heat treatment show that the homogeneity range of $\mathrm{UMOC}_{2}$ increases slightly with increasing temperature.

Alloy M-12 in Table 1 (43 a/o uranium-49 a/o carbon-8 a/o molybdenum) had the as-cast structure shown in Figure 9. This structure shows primary dendritic crystals of $\mathrm{UC}$ in a eutectic matrix which consists primarily of $\mathrm{UC}$ and $\mathrm{UMoC}_{2}$. The eutectic composition appears to be near 13 a/o molybdenum.

Alloy M-14 (21 a/o uranium-57 a/o carbon-22 a/o molybdenum) had the as-cast structure shown in Figure 10. This is apparently the eutectic composition on a pseudobinary tie line from graphite to $\mathrm{UMOC}_{2}$.

\section{Ternary Sections}

The ternary phase relationships derived from data in the literature and from the above studies may be summarized in terms of ternary isothermal sections, as shown in Figures 11, 12, and 13. The number 3 is used on these sections to designate a threephase field, the components of which may be found at the corners of each such field. Vertical sections from UC to molybdenum and from graphite to uranium-50 a/o molybdenum alloy are shown as Figures 14 and 15. 


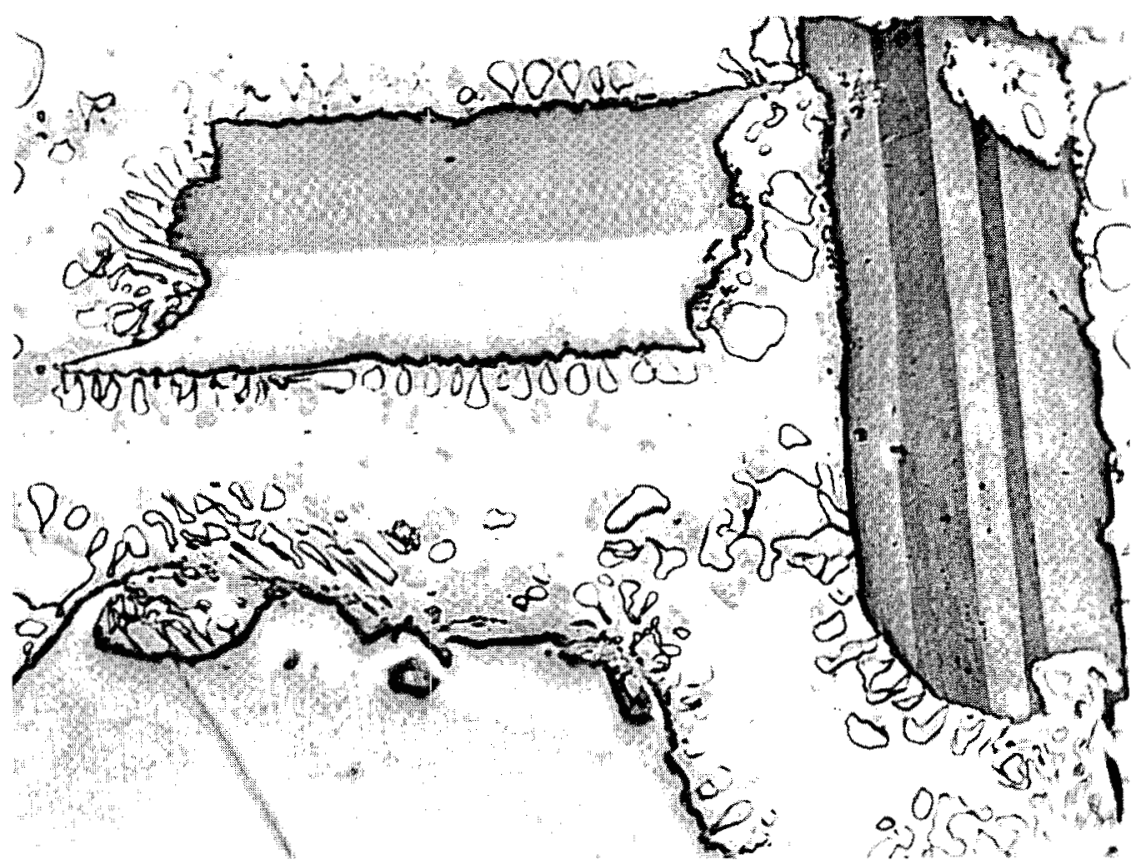

$750 \mathrm{X}$

$\mathrm{RM} 27756$

FIGURE 6. STRUCTURE OF 33 a $/ 0$ URANIUM-33 a $/ 0$ CARBON-33 a /o MOLYBDENUM ALLOY ANNEALED $1 / 2$ HR AT $1900 \mathrm{C}$

Striated phase is $\mathrm{UMoC}_{2}$. Black-outlined, white globules are molybdenum. Gray and white matrix is a mixture of UC and molybdenum which was liquid at $1900 \mathrm{C}$.

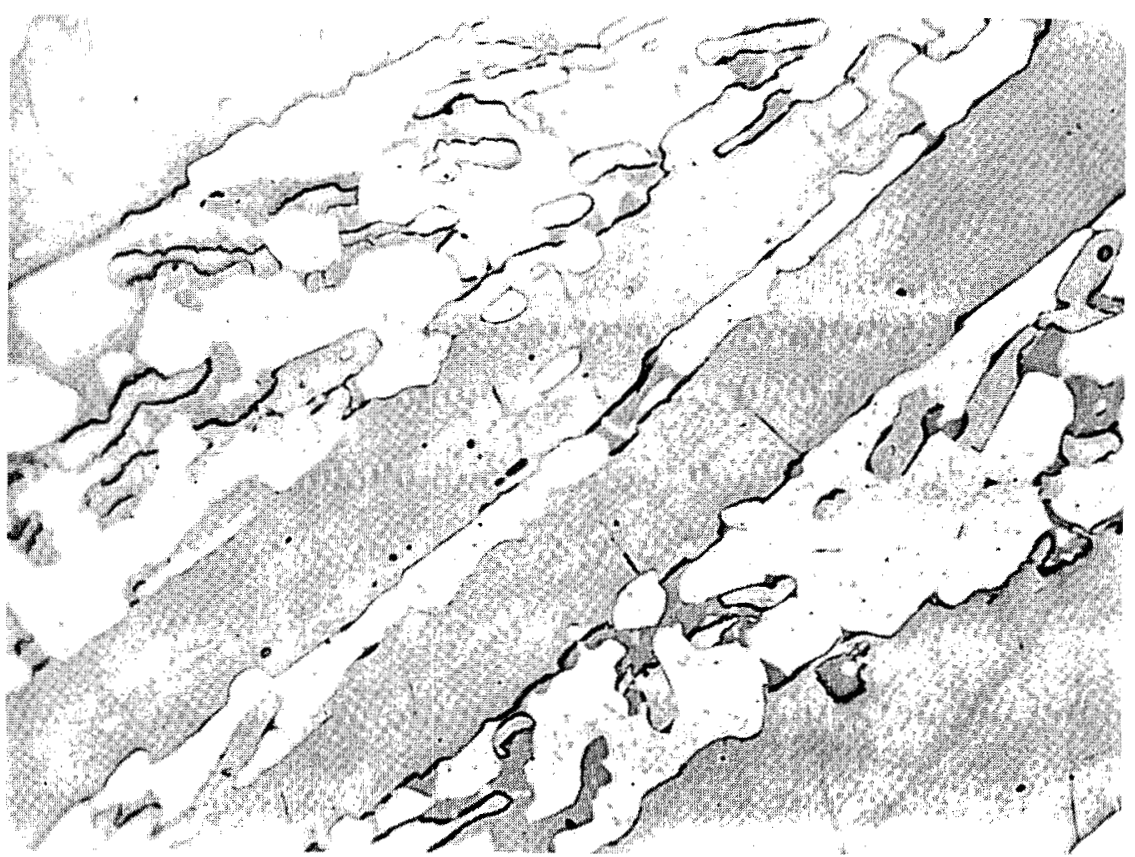

RM27761

FIGURE 7. STRUCTURE OF 20 a $/ 0$ URANIUM-30 a $/ 0$ CARBON -50 a $/ 0$ MOLYBDENUM ALLOY ANNEALED $1 / 2$ HR AT $1900 \mathrm{C}$

Long gray phase is $\mathrm{UMoC}_{2}$. White areas are molybdenum. Minor, dark gray phase is UC, which was part of an intergranular liquid at $1900 \mathrm{C}$. 


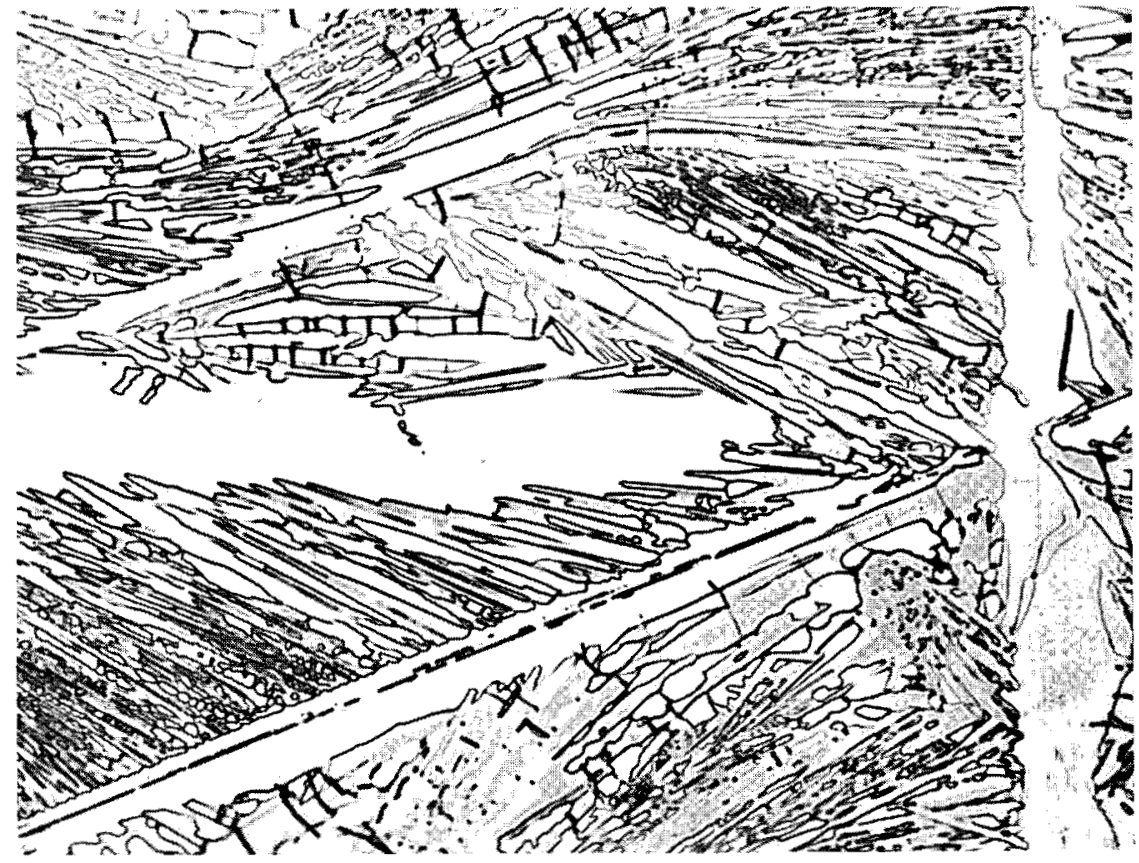

$750 \mathrm{X}$

RM26060

FIGURE 8. AS-CAST STRUCTURE OF 12 a $/ 0$ URANIUM-38 a $/ 0$ CARBON-50 a $/ 0$ MOLYBDENUM ALLOY

A few primary white needles of $\mathrm{Mo}_{2} \mathrm{C}$ are visible in a matrix of a eutectic containing $\mathrm{UMoC}_{2}$ and $\mathrm{Mo}_{2} \mathrm{C}$.

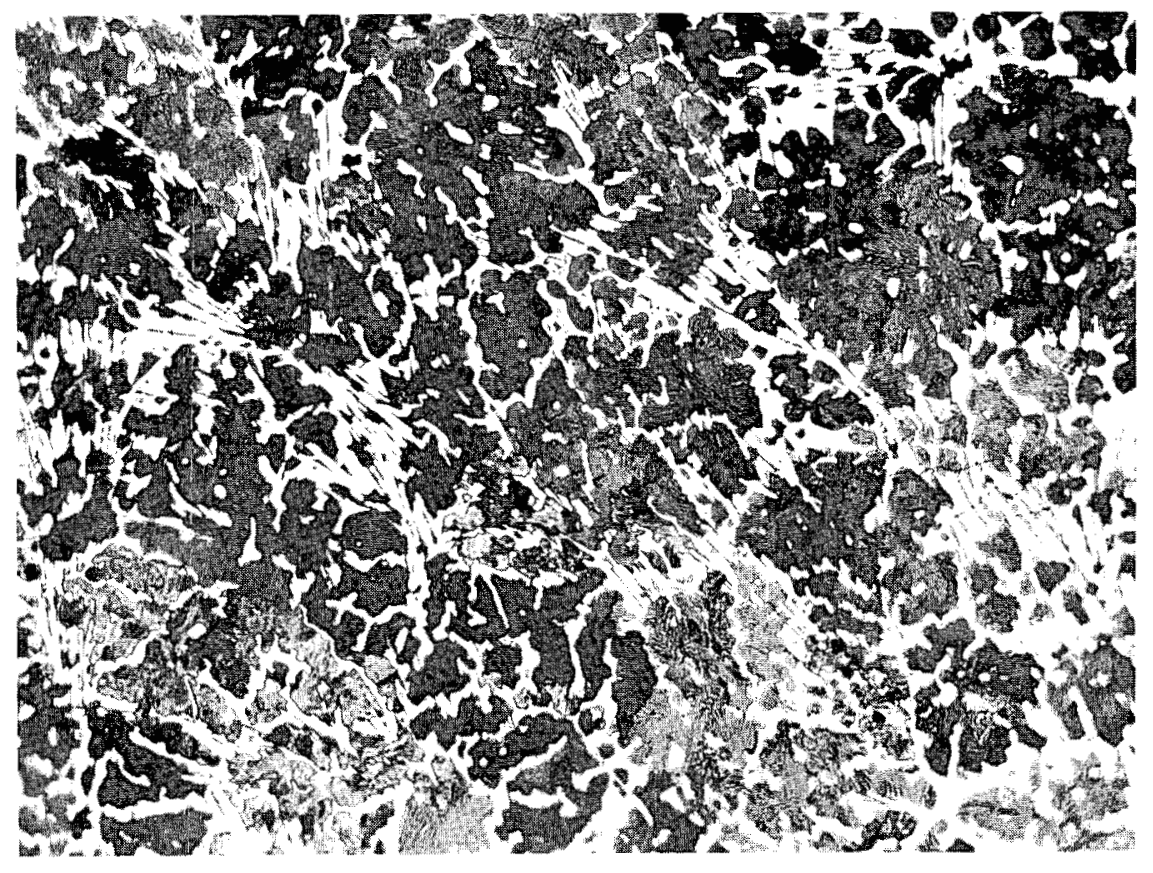

FIGURE 9. AS-CAST STRUCTURE OF 43 a $/ 0$ URANIUM-49 a /O CARBON8 a $/ 0$ MOLYBDENUM ALLOY

Black phase is UC; white phase is $\mathrm{UMOC}_{2}$. 


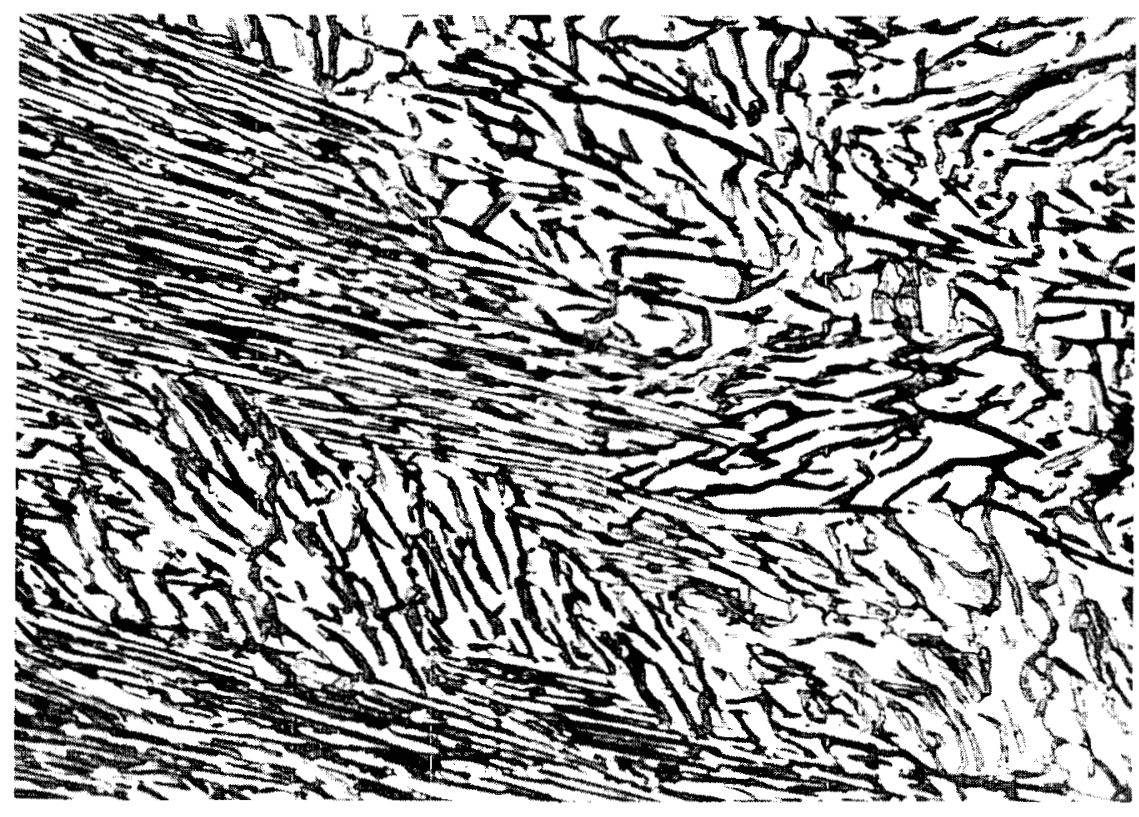

$500 \mathrm{X}$

RM27195

FIGURE 10. AS-CAST STRUCTURE OF 21 a /o URANIUM-57 a /o CARBON-22 a/o MOLYBDENUM ALLOY

White phase is $\mathrm{UMoC}_{2}$; black phase is graphite.

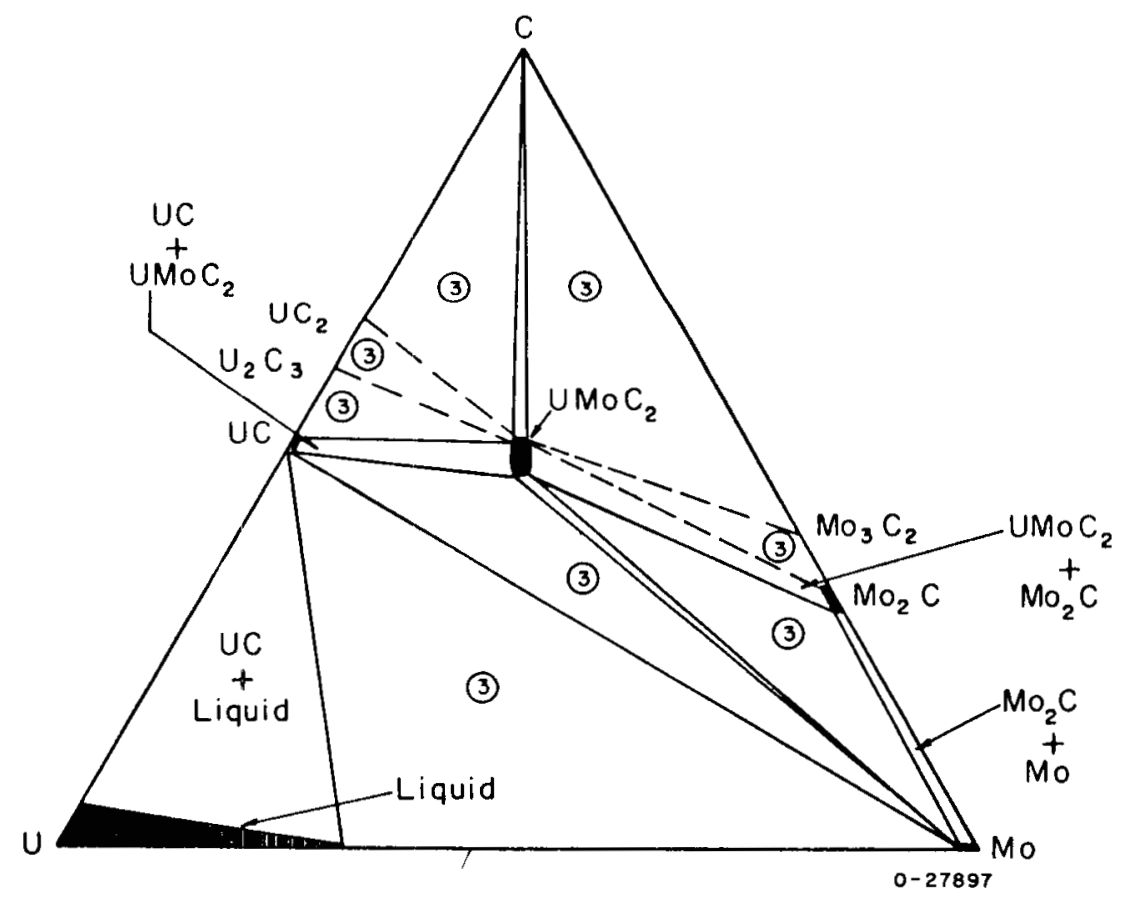

FIGURE 11. URANIUM-CARBON-MOLYBDENUM SYSTEM AT $1500 \mathrm{C}$ 


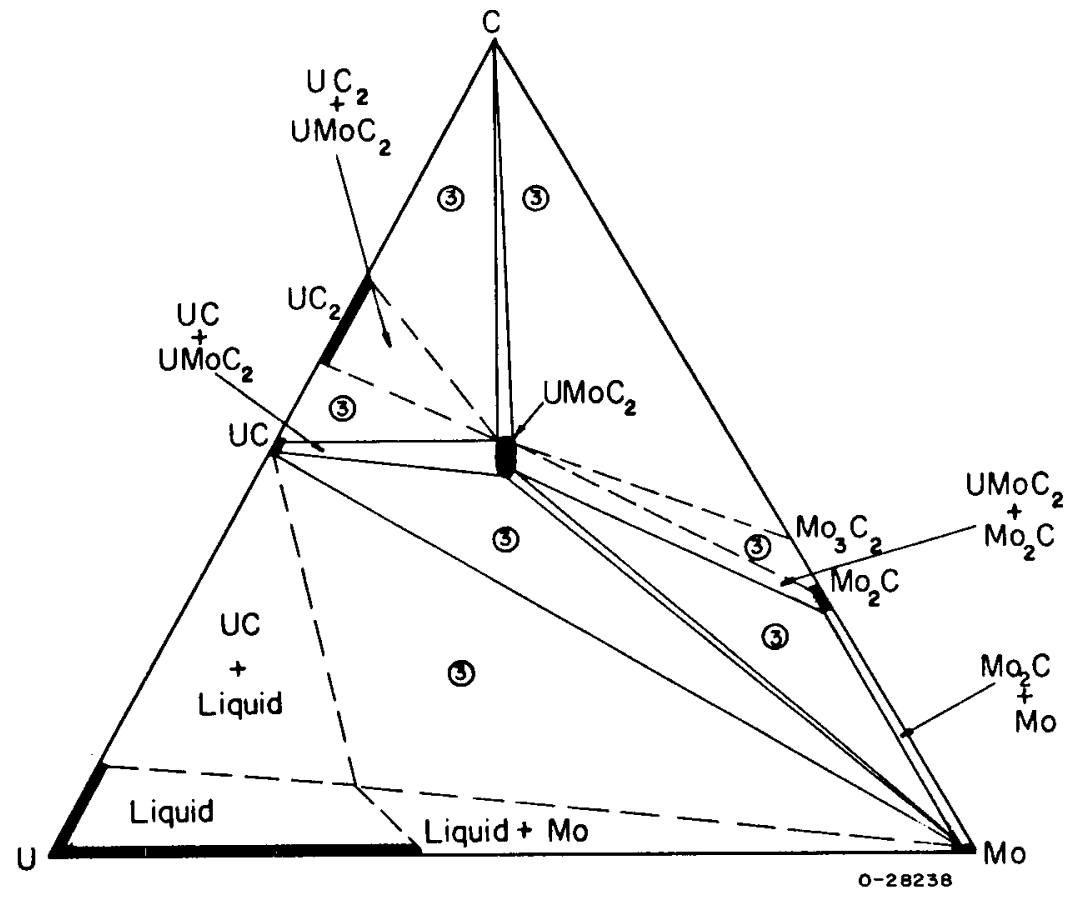

FIGURE 12. URANIUM-CARBON-MOLYBDENUM SYSTEM AT $1800 \mathrm{C}$

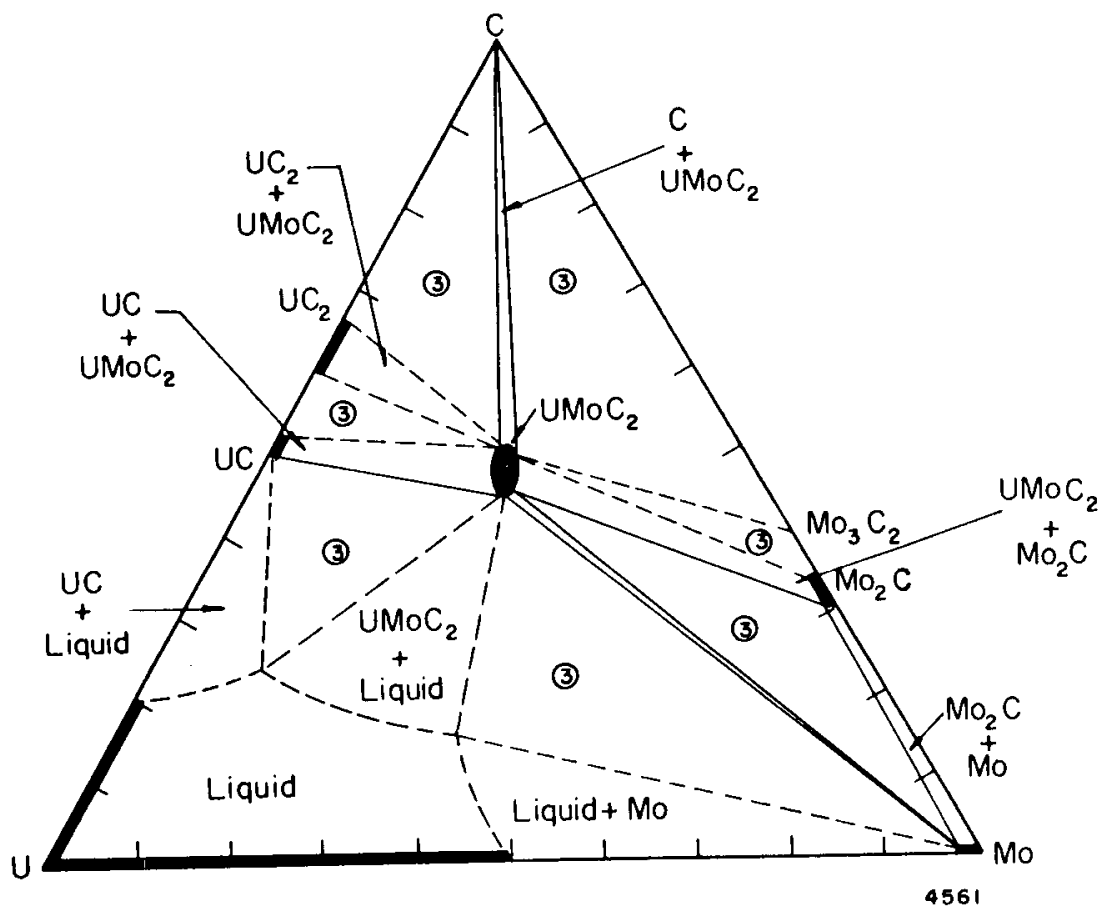

FIGURE 13. URANIUM-CARBON-MOLYBDENUM SYSTEM AT $2000 \mathrm{C}$ 


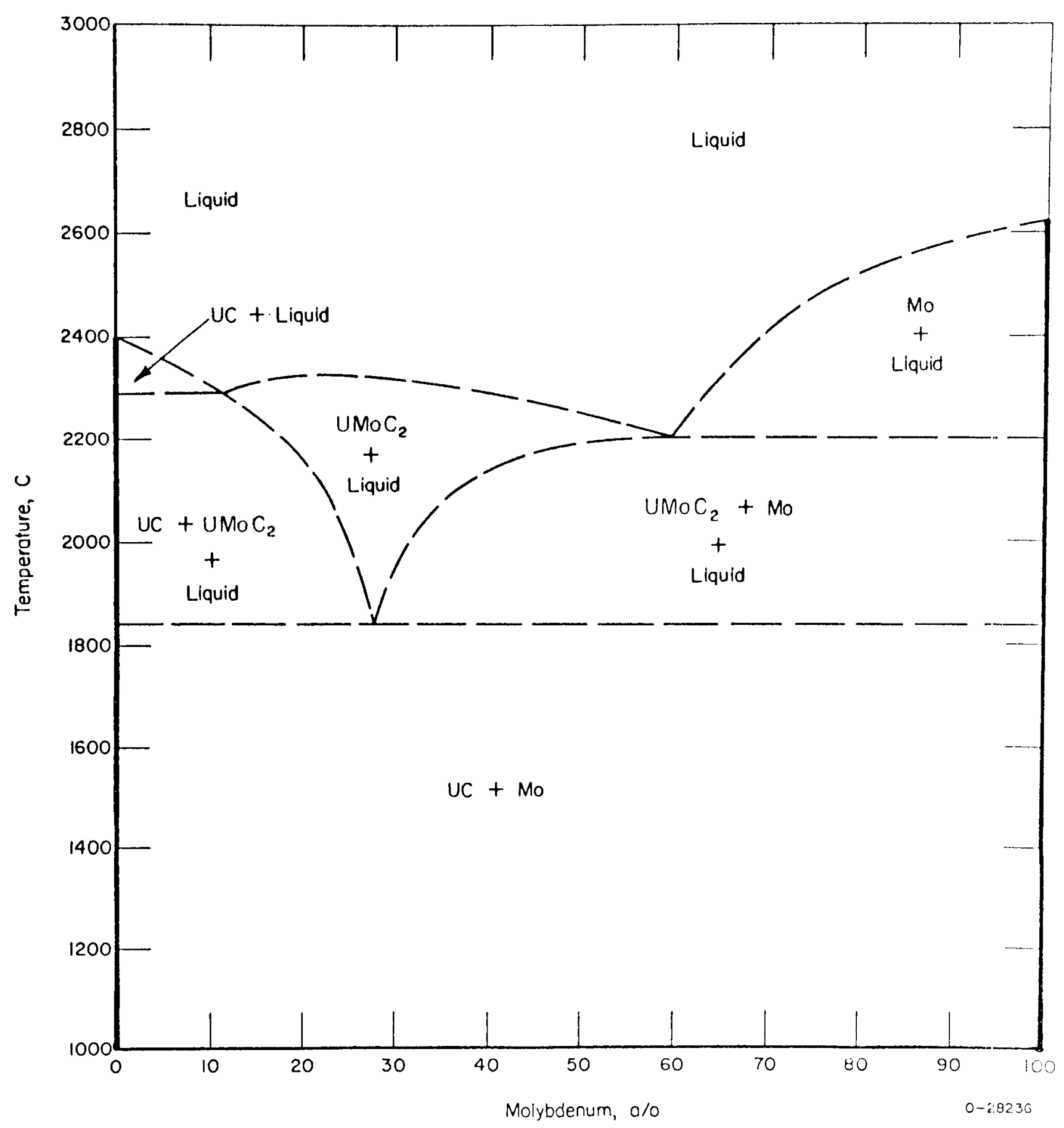

FIGURE 14. SECTION FROM URANIUM MONOCARBIDE TO MOLYBDENUM 


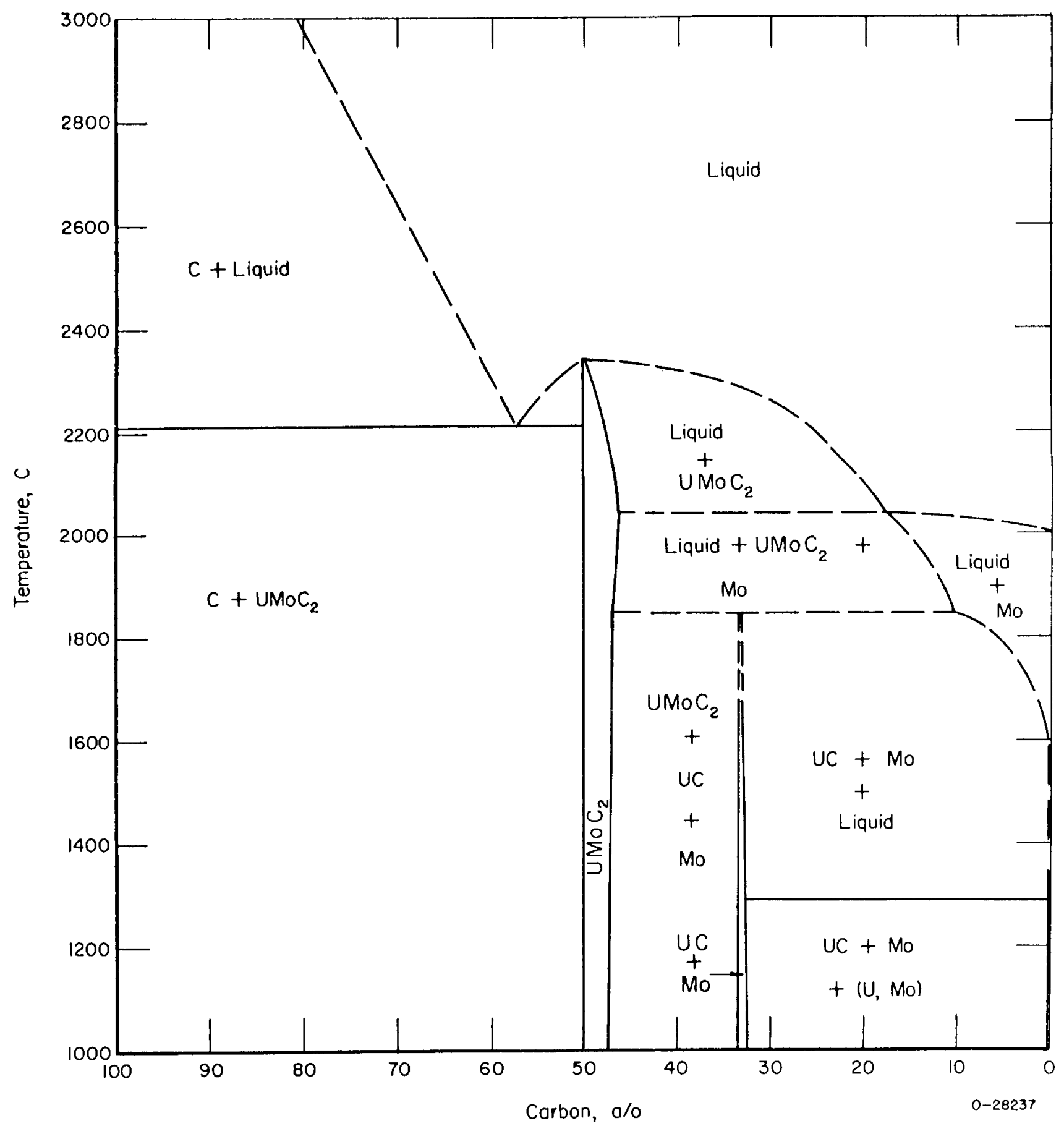

FIGURE 15. SECTION FROM CARBON TO URANIUM - 50 a/ O MOLYBDENUM ALLOY 
URANIUM-CARBON-NIOBIUM SYSTEM

$\underline{\text { Background }}$

The melting point of $\mathrm{NbC}$ varies over its range of homogeneity and reaches a maximum of about $3500 \mathrm{C}$ at a composition near 47 a/o carbon. $\mathrm{Nb}_{2} \mathrm{C}$ decomposes peritectically on heating to about $3100 \mathrm{C}$. (12)

The existence of complete solubility between $\mathrm{NbC}$ and $\mathrm{UC}$ has been established. $(9,13,14)$ The liquidus line for the pseudobinary system UC-NbC is a smocith curve between the terminal compositions. (13)

The (U, Nb)C solid solution exists in equilibrium with carbon at compositions which increase in $\mathrm{NbC}$ content with increasing temperature. The tendency for carbon to react with $(\mathrm{U}, \mathrm{Nb}) \mathrm{C}$ to form $\mathrm{UC}_{2}$ and a $(\mathrm{U}, \mathrm{Nb}) \mathrm{C}$ solution richer in $\mathrm{NbC}$ increases with increasing temperature. $\mathrm{UC}_{2}$ dissolves a negligible amount of niobium. (15)

The (U, Nb)C solid solution exists in equilibrium with carbon above 54 mole per cent $\mathrm{NbC}$ at $1600 \mathrm{C}$, above 55 mole per cent $\mathrm{NbC}$ at $1800 \mathrm{C}$, and above 63 mole per cent at 2000 C. (16) niobium. (18)

Niobium displaces uranium from UC. (17) The uranium contains essentially no

\section{$\underline{\text { Crystallography }}$}

$\mathrm{NbC}$ is face-centered cubic ( $\mathrm{NaCl}$ type), having four molecules per unit cell, with

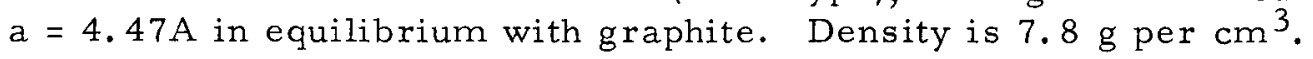

$\mathrm{Nb}_{2} \mathrm{C}$ is hexagonal close-packed (L'3 type), having one molecule per unit cell, with $\mathrm{a}=3.12$ and $\mathrm{c}=4.97 \mathrm{~A}$ in equilibrium with $\mathrm{NbC}$. Density is $7.9 \mathrm{~g}$ per $\mathrm{cm}^{3}$.

\section{Experimental Results}

An alloy was prepared by arc melting to consist of $\mathrm{UC}_{2}$ plus approximately 10 a/o niobium. The structure of the cast alloy is shown in Figure 16. This structure consists of primary dendrites plus a eutectic. The primary dentrites have the etching characteristics of the $\mathrm{NbC}-\mathrm{rich}(\mathrm{Nb}, \mathrm{U}) \mathrm{C}$ solid solution. The relative amounts of the primary dendrites and eutectic show that the eutectic composition contains much less than 10 a/o niobium and probably less than 5 a/o niobium. It may be inferred that the eutectic temperature is similar to the minimum between pure $U C$ and $U C_{2}$, since the constituents of the eutectic are apparently nearly pure $\mathrm{UC}_{2}$ and a $(\mathrm{U}, \mathrm{Nb}) \mathrm{C}$ solid scilution containing an appreciable amount of $\mathrm{NbC}$, roughly all the niobium in the eutectic. This is in agreement with the above-mentioned finding that $\mathrm{UC}_{2}$ dissolves a negligible amount of niobium. 
A uranium-carbon alloy containing 49.7 a/o carbon was heated in contact with niobium at $1540 \mathrm{C}$. When sectioned, several thick two-phase zones were observed at the contact interface. From the niobium side these zones were identified as niobiumuranium solid solution plus $\mathrm{Nb}_{2} \mathrm{C}, \mathrm{Nb}_{2} \mathrm{C}$ plus uranium metal, and ( $\left.\mathrm{Nb}, \mathrm{U}\right) \mathrm{C}$ solid solution plus uranium metal. Electron-probe microanalyses were obtained of the various phases at several points in these zones. At a point near the interface between the $\mathrm{Nb}_{2} \mathrm{C}$ and the (Nb, $\left.\mathrm{U}\right) \mathrm{C}$ zones, the $\mathrm{Nb}_{2} \mathrm{C}$ particles were found to contain between 0.3 and 0.7 a/o uranium. At this point, the $(\mathrm{Nb}, \mathrm{U}) \mathrm{C}$ contained only 0.6 a/o uranium and the metallic uranium obtained no niobium. It is considered likely that the metallic uranium contained traces of niobium and carbon in liquid solution at $1540 \mathrm{C}$, but that this was divorced from the liquid on cooling. No information was obtained from the electron-probe microanalyzer with regard to the carbon contents of any of the phases so that the following additional studies were undertaken.

The seven NbC-rich alloys shown in Table 2 were prepared by arc melting. The cast alloys were sectioned and analyzed for carbon and uranium. The phases present were identified by metallographic observation and by hardness measurements. The minor phases present were identified as uranium metal and $\mathrm{Nb}_{2} \mathrm{C}$, and the combined volume of these was determined by point counting. Using these data (also shown in Table 2) and the lever law, several compositions corresponding to the solubility limit for uranium in ( $\mathrm{Nb}, \mathrm{U}) \mathrm{C}$ and in $\mathrm{Nb}_{2} \mathrm{C}$ were calculated. Alloys $\mathrm{N}-1$ and $\mathrm{N}-2$ indicate that a composition of 14 a/o uranium-48 to 49 a/o carbon-balance niobium lies on the solubility-limit line for uranium in $(\mathrm{Nb}, \mathrm{U}) \mathrm{C}$. Alloy $\mathrm{N}-3$ indicates that a composition of 2 a/o uranium-49 a/o carbon-balance niobium lies on the solubility-limit line for uranium in NbC. Alloy $\mathrm{N}-4$ indicates that at 46 a/o carbon and 53 a/o niobium, $\mathrm{NbC}$ will contain less than $\mathrm{l}$ a/o uranium in solution. The appearance of $\mathrm{Nb}_{2} \mathrm{C}$ in Alloy $\mathrm{N}-5$ shows that the $\mathrm{NbC}$ corner of the ternary region, $\mathrm{NbC}$ plus $\mathrm{Nb}_{2} \mathrm{C}$ plus uranium metal, lies very near 45 a/o carbon, 54 a/o niobium, and less than 1 a/o uranium. The presence of $\mathrm{NbC}$ in Alloy $\mathrm{N}-7$ suggests that the ternary region, $\mathrm{NbC}$ plus $\mathrm{Nb}_{2} \mathrm{C}$ plus uranium metal, is very extensive and that the $\mathrm{Nb}_{2} \mathrm{C}$ corner of this region extends at least to the lower limit of the existence range of $\mathrm{Nb}_{2} \mathrm{C}$ at temperatures near the solidus. Since $\mathrm{Nb}_{2} \mathrm{C}$ forms by peritectic reaction, this point may shift to higher carbon contents at lower temperatures.

TABLE 2. VOLUME OF MINOR PHASES FOUND IN AS-CAST NIOBIUM-URANIUMCARBON ALLOYS

\begin{tabular}{|c|c|c|c|c|c|}
\hline \multirow{3}{*}{ Alloy } & \multirow{2}{*}{\multicolumn{3}{|c|}{$\begin{array}{c}\text { Analyzed Composition, } \\
\mathrm{a} / \mathrm{o} \\
\end{array}$}} & \multicolumn{2}{|c|}{ Minor Phases Present } \\
\hline & & & & & Amount Present, \\
\hline & U & C & $\mathrm{Nb}(\mathrm{a})$ & Identity & \\
\hline $\mathrm{N}-1$ & 20.2 & 44.5 & 35 & Uranium metal & 5 \\
\hline$N-2$ & 14.2 & 47.8 & 38 & Not identified(b) & 1.4 \\
\hline$N-3$ & 10.1 & 44.9 & 45 & Uranium metal & 8 \\
\hline$N-4$ & 5.2 & 44.1 & 50 & Uranium metal & 4.4 \\
\hline$N-5$ & 5.2 & 39.7 & 55 & $\mathrm{Nb}_{2} \mathrm{C}$, uranium metal(b) & 15 \\
\hline$N-6$ & 5.3 & 34.2 & 60 & $\mathrm{Nb}_{2} \mathrm{C}$, uranium metal & 12 \\
\hline$N-7$ & 5.2 & 27.8 & 67 & $\mathrm{Nb}_{2} \mathrm{C}$, uranium metal $(\mathrm{c})$ & 29 \\
\hline
\end{tabular}

(a) By difference.

(b) Major phase, (Nb, U)C, had a hardness of $3200 \mathrm{KHN}$.

(c) Minor phase, $\mathrm{Nb}_{2} \mathrm{C}$, had a hardness of $1780 \mathrm{KHN}$. 
Ternary Sections

The ternary phase relationships derived from data from the literature and from the above studies may be summarized in terms of ternary isothermal sections. Figure 17 shows a section at $1300 \mathrm{C}$. At this temperature $\mathrm{UC}_{2}$ is unstable and $\mathrm{U}_{2} \mathrm{C}_{3}$ dominates the high-carbon, high-uranium portion of the diagram. Since $\mathrm{NbC}$ and $\mathrm{Nb}_{2} \mathrm{C}$ are much more stable than UC, liquid uranium metal dominates the low-carbon, high-uranium portion of the diagram. Figure 18 shows a section at $1700 \mathrm{C}$. Figure 19 shows $a$. section at $2200 \mathrm{C}$ which illustrates the growing stability and range of homogeneity of $\mathrm{UC}_{2}$ with increasing temperature.

\section{URANIUM-CARBON-RHENIUM SYSTEM}

Background

Eutectic melting is observed between UC and rhenium metal at about 1900 C. (19)

Crystallography

$\mathrm{UReC}_{2}$ is orthorhombic ( $\mathrm{UCrC}_{2}$ type), having four molecules per unit cell, with $\mathrm{a}=5.52, \mathrm{~b}=3.20$, and $\mathrm{c}=10.88 \mathrm{~A}$. Density is $15.5 \mathrm{~g}$ per $\mathrm{cm}^{3}$.

Experimental Results

The four alloys shown in Table 3 were prepared by arc melting to determine the presence or absence of possible pseudobinary tie lines in the uranium-carbon-rhenium system at and below 50 a/o carbon. The alloys were prepared from spectrographic graphite, biscuit uranium, and commercial rhenium bar stock. A spectrographi: analysis of the rhenium bar indicated no tungsten in this material. The arc-melted buttons were broken into several pieces and examined by $X$-ray diffraction and metallographic methods. A piece of each alloy was wrapped in tantalum foil and heat treated for $3 \mathrm{hr}$ at $1500 \mathrm{C}$. The heat-treated pieces were further examined by metallographic methods, and Alloy R-4, which appeared to be radically changed by the heat treatment, was further examined by $\mathrm{X}$-ray diffraction.

The phases found by metallographic and X-ray examination both before and after heat treatment at $1500 \mathrm{C}$ were the same, and it must be concluded that there are no major changes in the uranium-carbon-rhenium system between $1500 \mathrm{C}$ and the solidus temperature in the region of compositions examined. The phases identified are shown in Table 3. The as-cast structure of the $\mathrm{UReC}_{2}$ phase (Alloy $\mathrm{R}-1$ ) is shown in Fig20. A small amount of excess rhenium is apparently present in the microstructure, but this was not detected by $\mathrm{X}$-ray. The $\mathrm{UReC}_{2}$ phase is isostructural with $\mathrm{UCrC}_{2}$. Alloy R-1 had a hardness of $1390 \mathrm{~kg}$ per $\mathrm{mm}^{2}$. The as-cast structure of Alloy $\mathrm{R} \cdot 2$ is shown in Figure 21. This structure consists of a few primary dendrites of rhenium 


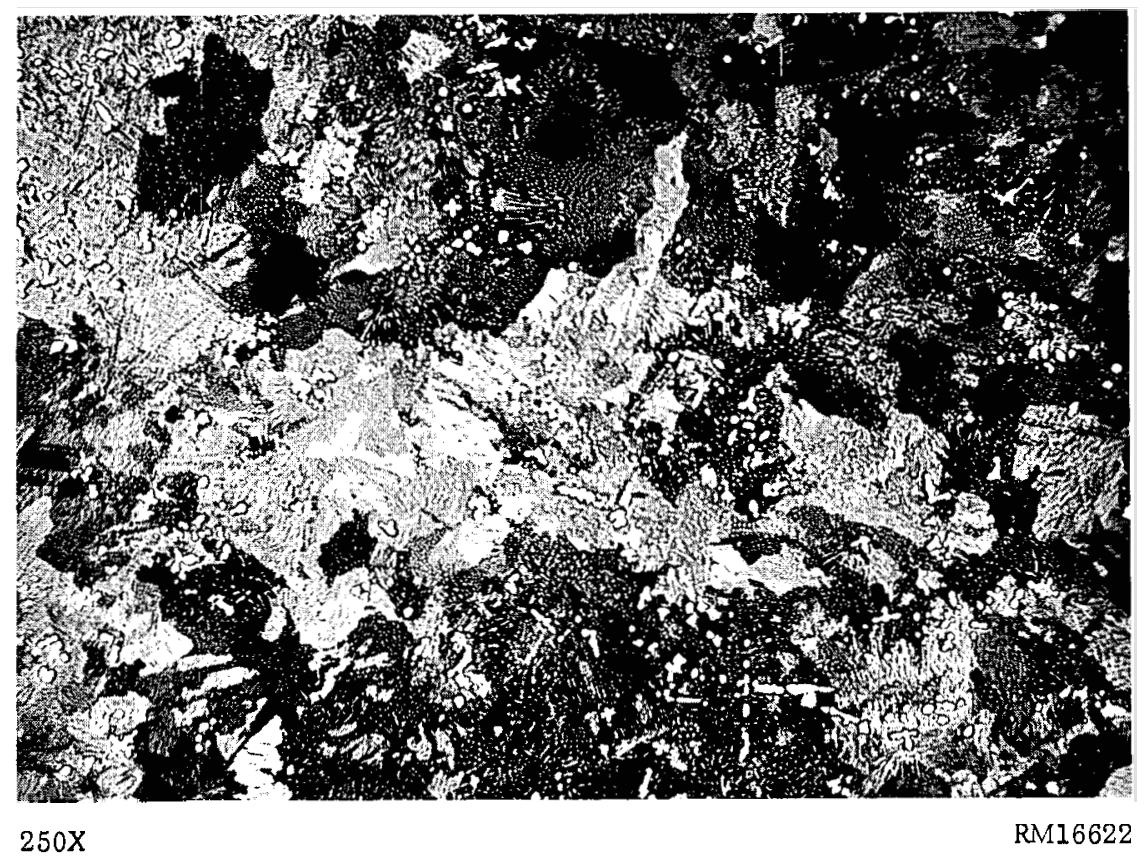

FIGURE 16. AS-CAST STRUCTURE OF AN ALLOY OF UC, PLUS 10 a $/ 0$ NIOBIUM Structure shows primary $\mathrm{NbC}$-rich dendrites plus a $(\mathrm{U}, \mathrm{Nb}) \mathrm{C}-\mathrm{UC}_{2}$ eutectic.

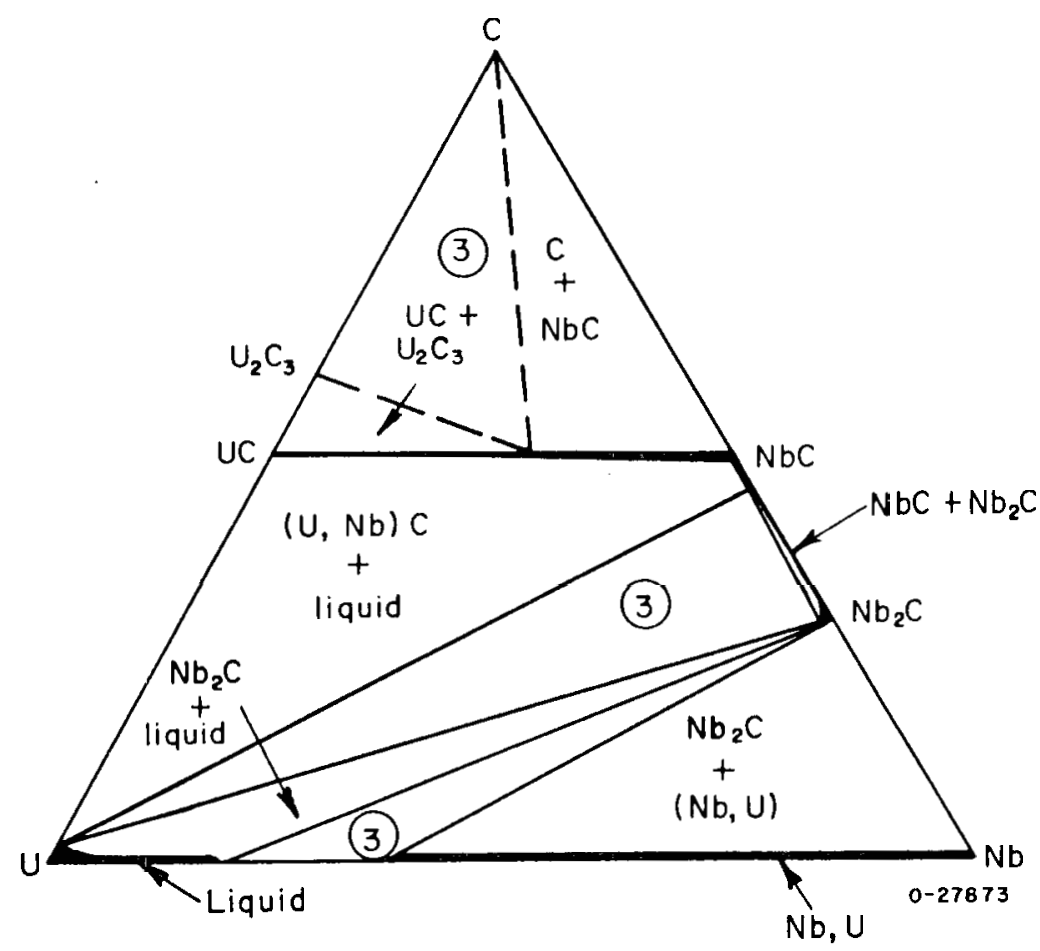

FIGURE 17. URANIUM-CARBON-NIOBIUM SYSTEM AT $1300 \mathrm{C}$ 


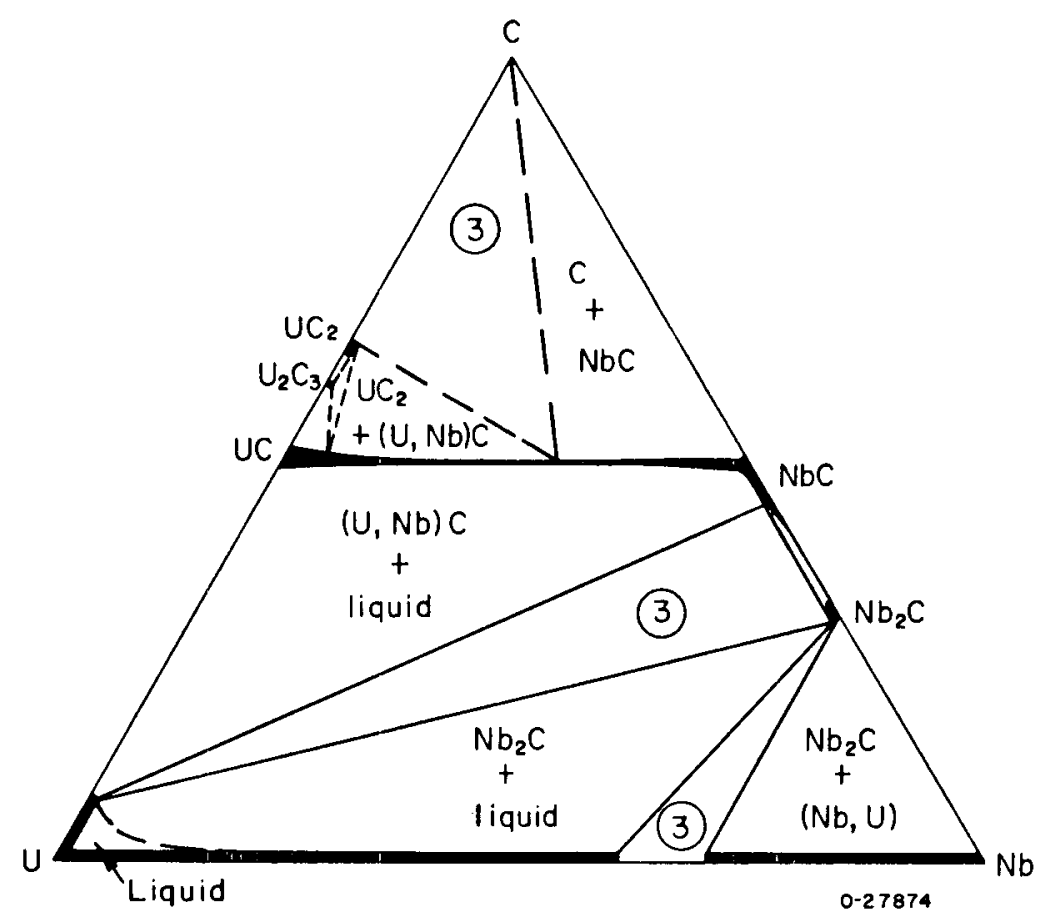

FIGURE 18. URANIUM-CARBON-NIOBIUM SYSTEM AT $1700 \mathrm{C}$

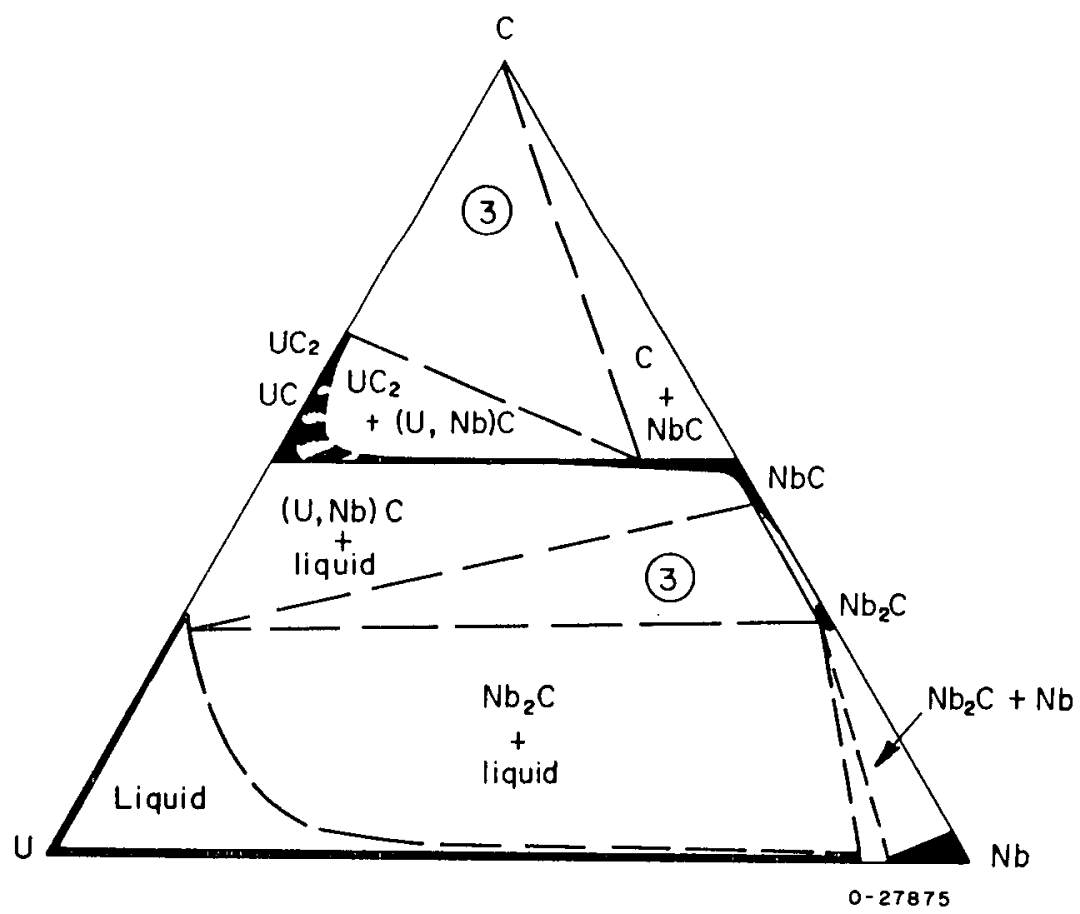

FIGURE 19. URANIUM-CARBON-NIOBIUM SYSTEM AT $2200 \mathrm{C}$ 
metal in a background composed of the UC-rhenium eutectic. The UC-rhenium eutectic is evidently near 35 a/o uranium, 35 a/o carbon, and 30 a/o rhenium. The as-cast structure of Alloy R-4 in Table 3 is shown in Figure 22. This structure consists of a primary dendrite of $\mathrm{URe}_{2}$ in a background composed of the UC-URe $\mathrm{U}_{2}$ eutectic. The UC-URe 2 eutectic is evidently near 41 a/o uranium, 29 a/o carbon, and 35 a/o rhenium.

\section{TABLE 3. PHASES FOUND IN URANIUM-CARBON- RHENIUM ALLOYS}

\begin{tabular}{|c|c|c|c|c|}
\hline \multirow[b]{2}{*}{ Alloy } & \multicolumn{3}{|c|}{$\begin{array}{c}\text { Nominal Composition, } \\
\mathrm{a} / \mathrm{o}\end{array}$} & \multirow{2}{*}{$\begin{array}{c}\text { Phases Identified by } \\
\text { Metallographic and } \\
\text { X-Ray Methods }\end{array}$} \\
\hline & $\mathrm{U}$ & $\mathrm{C}$ & $\mathrm{Re}$ & \\
\hline$R-1$ & 25 & 50 & 25 & $\mathrm{UReC}_{2}(\mathrm{a})$ \\
\hline $\mathrm{R}-2$ & 30 & 30 & 40 & Rhenium, UC \\
\hline$R-3$ & 35 & 25 & 40 & $\mathrm{UC}, \mathrm{URe}_{2}$, rhenium \\
\hline $\mathrm{R}-4$ & 40 & 20 & 40 & $\mathrm{UC}, \mathrm{URe}_{2}$ \\
\hline
\end{tabular}

(a) Alloy hardness was $1390 \mathrm{~kg}$ per $\mathrm{mm}^{2}$.

\section{Ternary Section}

The ternary phase relationships derived from the above data are shown in Figure 23.

\section{URANIUM-CARBON-TUNGSTEN SYSTEM}

\section{Background}

WC decomposes on heating at about $2750 \mathrm{C} . \mathrm{W}_{3} \mathrm{C}_{2}$ exists as a stable phase only in the temperature range from 2525 to $2780 \mathrm{C}$. $\mathrm{W}_{2} \mathrm{C}$ melts congruently at $2800 \mathrm{C}$ and exists over a composition range from approximately 28 a/o to 33 a/o carbon. (20)

A ternary compound $U_{W} C_{2}$ exists between $U C$ and WC. (11) $U_{W} C_{2}$ melts at $2575 \mathrm{C}$ and has a hardness of $1900 \mathrm{~kg}$ per $\mathrm{mm}^{2}$. A eutectic exists between $\mathrm{UWC}_{2}$ and graphite at $2360 \mathrm{C}$. A ternary eutectic exists between $\mathrm{UWC}_{2}, \mathrm{UC}_{2}$, and graphite at 2275 C. (3)

Melting has been observed between UC and tungsten at $2280 \mathrm{C}$. (21) Melting has been observed between $U C$ and $W_{2} C$ at $2480 \mathrm{C}$, and between $U C$ and $W C$ at $2430 \mathrm{C}$. (22)

WC dissolves no UC(8), but UC dissolves a small amount of WC. The solubility of tungsten in UC has been reported as $5 \mathrm{a} / \mathrm{o}^{(8)}, 2$ to $4 \mathrm{a} / \mathrm{o}(23)$, and 1 a/o tungsten. (24) 


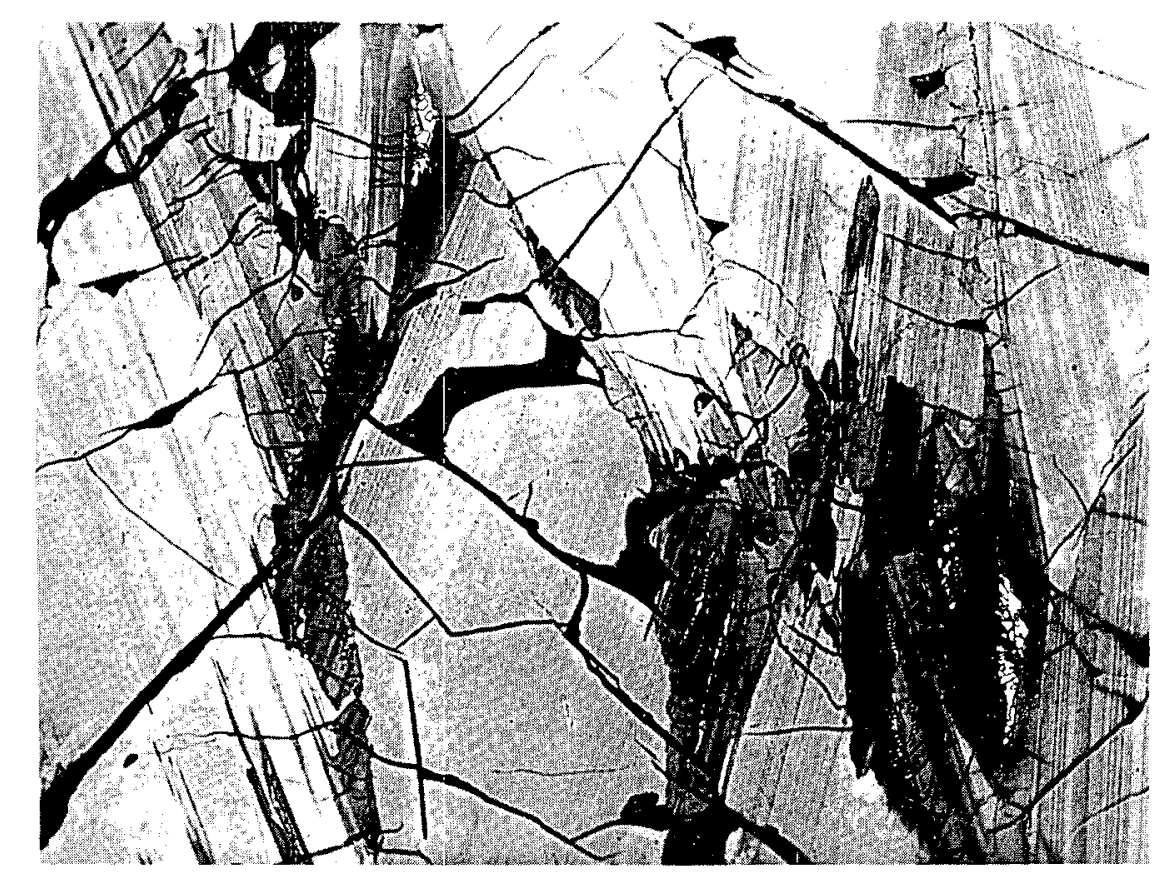

$250 \mathrm{X}$

RM22072A

FIGURE 20. AS-CAST STRUCTURE OF 25 a $/ 0$ URANIUM-50 a $/ 0$ CARBON-25 a $\%$ RHENIUM ALLOY Orthorhombic crystals of $\mathrm{URe}_{2}$, microcracks, and trace quantities of rhenium are visible.

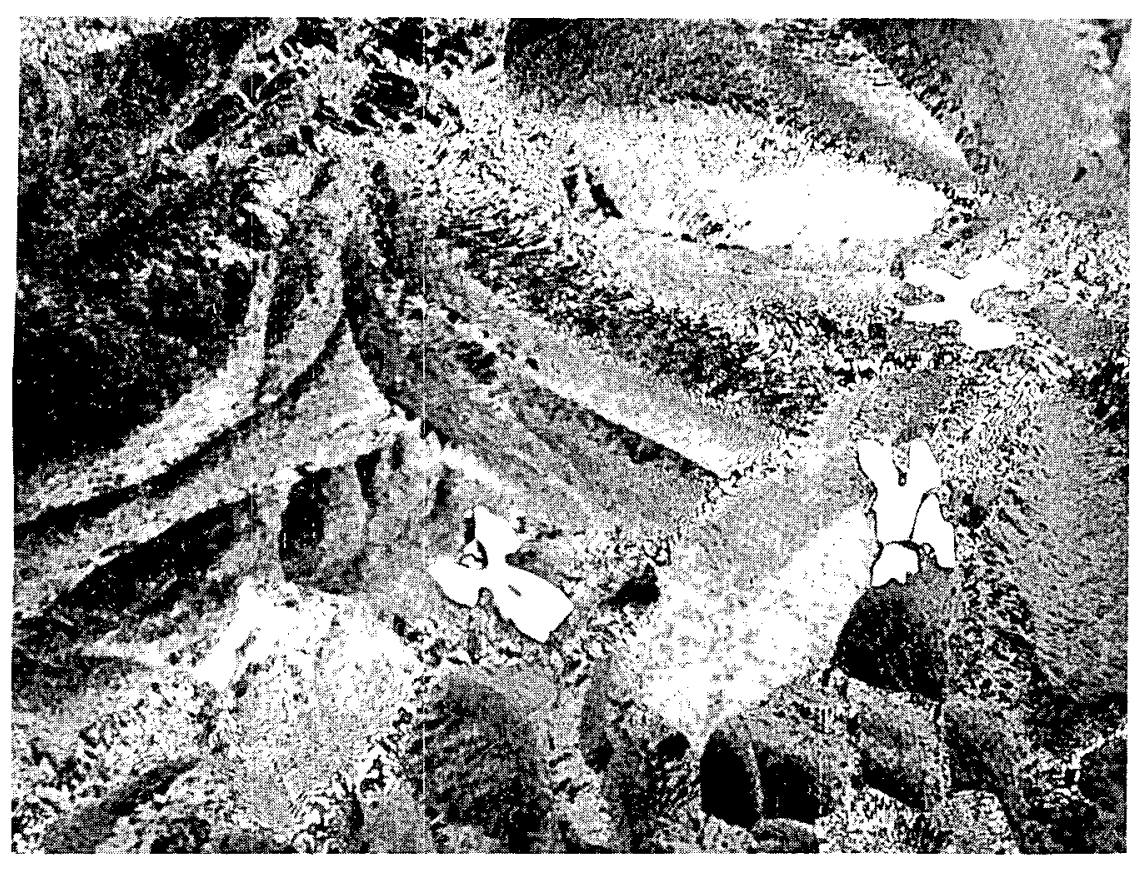

$500 \mathrm{X}$

RM22073A

FIGURE 21. AS-CAST STRUCTURE OF 30 a $/ 0$ URANIUM-30 a $/ 0$ CAKBON-40 a $/ 0$ RHENIUM ALLOY

White, primary dendrites of rhenium metal in a eutectic background mixture of UC and rhenium are shown. 


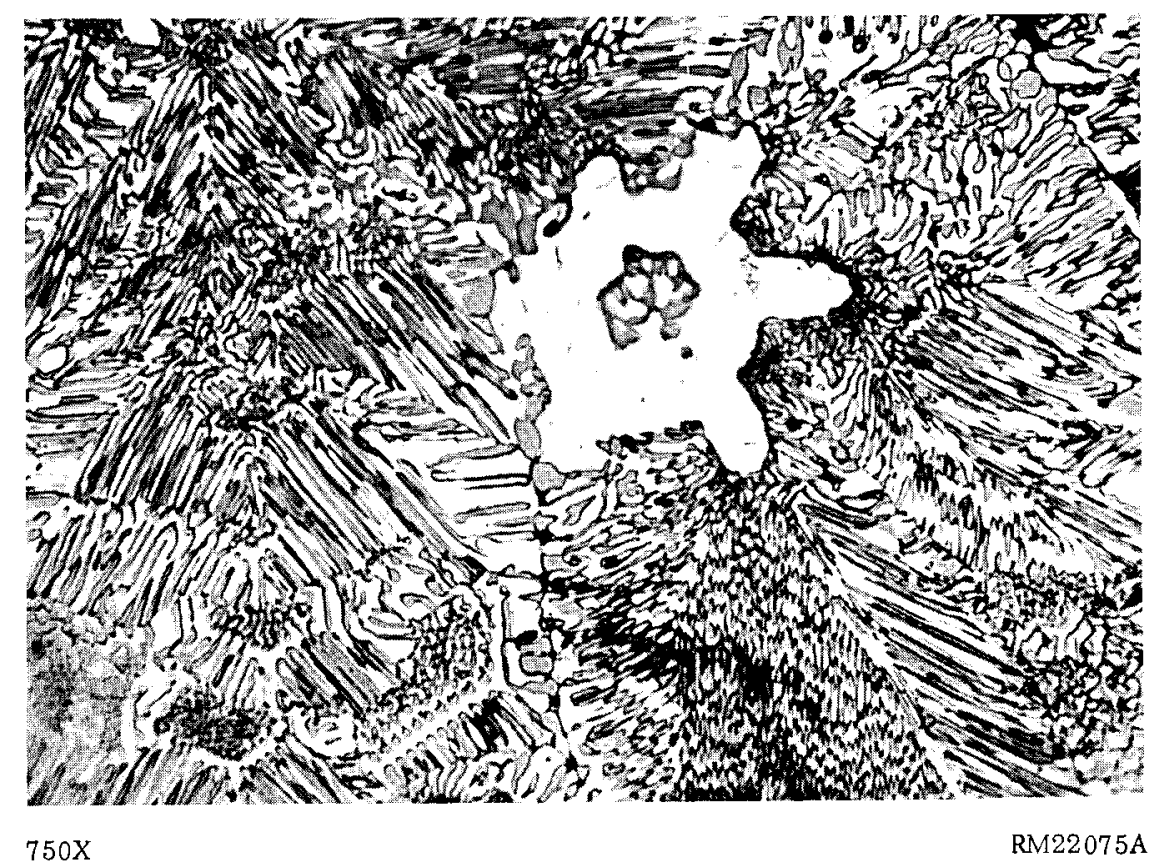

FIGURE 22. AS-CAST STRUCTURE OF 40 a $/ 0$ URANIUM-20 a $/ 0$ CARBON-40 a $/ 0$ RHENIUM ALLOY

White, primary dendrite of $\mathrm{URe}_{2}$ is visible in a eutectic background mixture of UC and URe ${ }_{2}$.

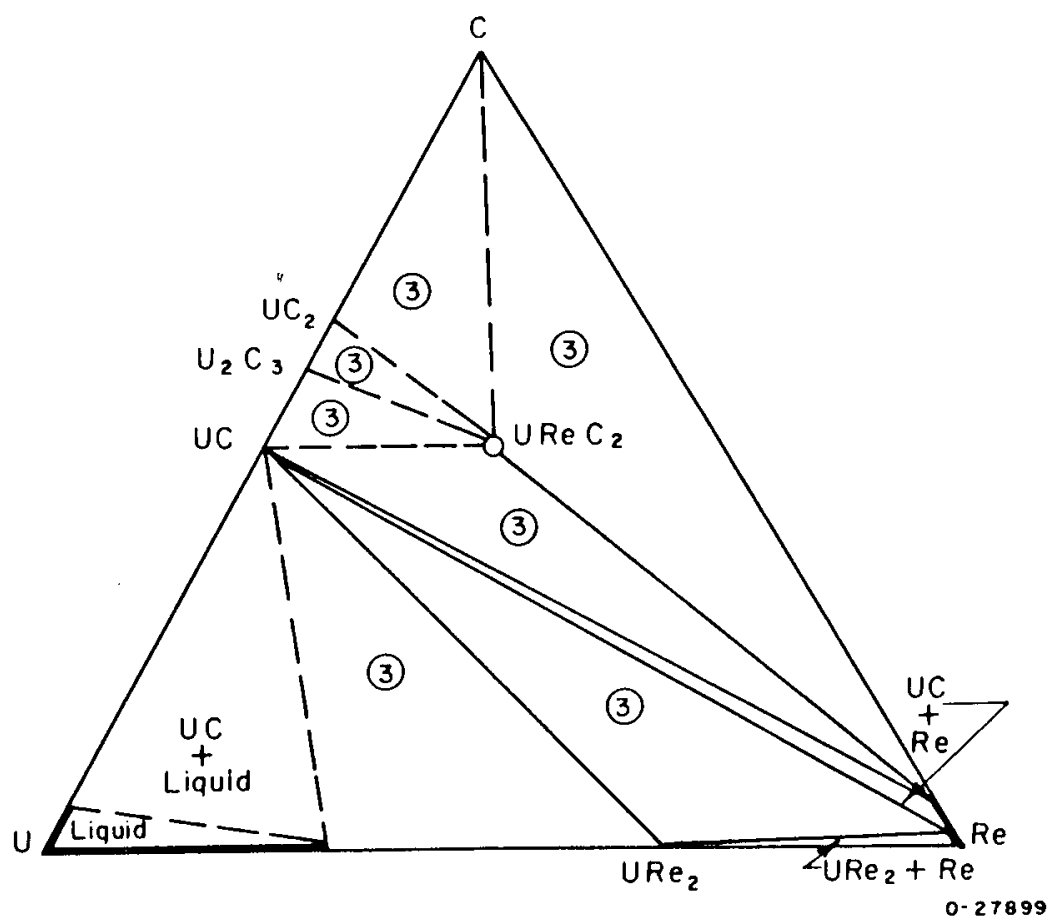

FIGURE 23. URANIUM-CARBON-RHENIUM SYSTEM AT $1500 \mathrm{C}$ 
A ternary section of the uranium-tungsten-carbon system at $1500 \mathrm{C}$ shows pseudobinary tie lines between $\mathrm{UC}$ and tungsten and between $\mathrm{UWC}_{2}$ and $\mathrm{UC}$, tungsten, $\mathrm{W}_{2} \mathrm{C}$, WC, carbon, $\mathrm{UC}_{2}$, and $\mathrm{U}_{2} \mathrm{C}_{3} .(25)$

\section{Crystallography}

$\mathrm{WC}$ is hexagonal, having one molecule per unit cell, with $\mathrm{a}=2.90$ and $\mathrm{c}=2.93 \mathrm{~A}$. Density is $15.5 \mathrm{~g}$ per $\mathrm{cm}^{3}$.

$\mathrm{W}_{3} \mathrm{C}_{2}$ is face-centered cubic, with $\mathrm{a}=4.13 \mathrm{~A} .(20)$

$\mathrm{W}_{2} \mathrm{C}$ is hexagonal close packed, having one molecule per unit cell, with $\mathrm{a}=2.99$ and $c=4.72 \mathrm{~A}$. Density is $17.2 \mathrm{~g}$ per $\mathrm{cm}^{3}$.

$\mathrm{UWC}_{2}$ is orthorhombic ( $\mathrm{UCrC}_{2}$ type), having four molecules per unit cell, with $\mathrm{a}=5.62, \mathrm{~b}=3.24$, and $\mathrm{c}=10.96 \mathrm{~A}$. Density is $14.8 \mathrm{~g} \mathrm{per} \mathrm{cm}^{3}$. (11)

\section{Experimental Results}

A number of alloys containing more than 50 a/o carbon, more than $30 \mathrm{a} / \mathrm{o}$ uranium, plus small amounts of tungsten, were prepared by arc melting. The structure of one such as-cast alloy is shown in Figure 24. The structure of this alloy, having a nominal composition of 65 a/o carbon, 32 a/o uranium, and 3 a/o tungsten, shows primary, rounded dendrites of $\mathrm{UC}_{2}$ plus an interdendritic eutectic presumed to consist of $\mathrm{UWC}_{2}$ and $\mathrm{UC}_{2}$. The lack of a secondary precipitate in the $\mathrm{UC}_{2}$ dendrites plus the relatively large amount of $\mathrm{UWC}_{2}$ in the eutectic in this structure indicates that there is no solubility of tungsten in $\mathrm{UC}_{2}$. Examination of this alloy and other alloys containing more tungsten suggests that the $\mathrm{UC}_{2}-\mathrm{UWC}_{2}$ eutectic is near 15 a/o tungsten, and that a UC-UWC 2 eutectic exists near 10 a/o tungsten. The solubility of tungsten in UC is less than $2 \mathrm{a} / \mathrm{o}$ ( 4 mole per cent WC) at low temperatures. The solubility increases with temperature and may exceed 5 mole per cent $W C$ at the eutectic temperature.

The three tungsten-rich alloys shown in Table 4 were prepared by arc melting to determine the pseudobinary tie lines at compositions below 50 a/o carbon. The alloys were prepared from spectrographic graphite, biscuit uranium, and commercial tungsten bar stock. The arc-melted buttons were broken into several pieces and examinec. by $\mathrm{X}$-ray diffraction and metallographic methods. A piece of each alloy was wrapped in tantalum foil and heat treated for $3 \mathrm{hr}$ at $1500 \mathrm{C}$. Metallographic examination of the heat-treated alloys disclosed changes in the distribution of the phases present, but no gross changes in the amounts of the phases. The phases identified are shown in Table 4 .

The heat-treated structure of Alloy $\mathrm{W}-1$ is shown in Figure 25. This structure shows large primary particles of $\mathrm{UWC}_{2}$ and a slightly coarsened eutectic of $\mathrm{W}_{2} \mathrm{C}$ and $\mathrm{UWC}_{2}$. The $\mathrm{W}_{2} \mathrm{C}-\mathrm{UWC}_{2}$ eutectic is evidently near 50 a/o tungsten, 40 a/o carbon, and 10 a/o uranium. 


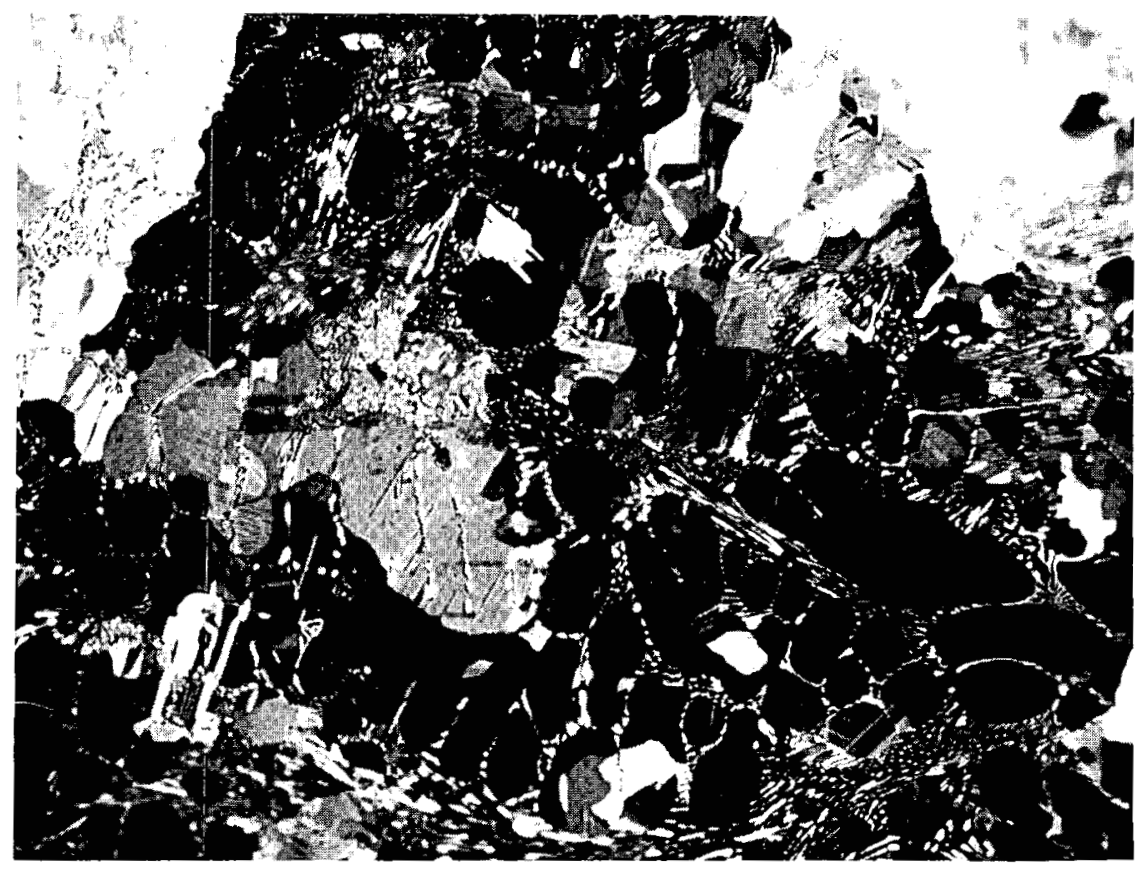

FIGURE 24. AS-CAST STRUCTURE OF AN ALLOY OF 65 a $/ 0$ CARBON, 32 a $/ 0$ URANIUM, AND 3 a $/ O$ TUNGSTEN (UC 2 PLUS 3 a /O TUNGSTEN)

Primary, rounded dendrites of $\mathrm{UC}_{2}$ plus an interdendritic eutectic are shown.

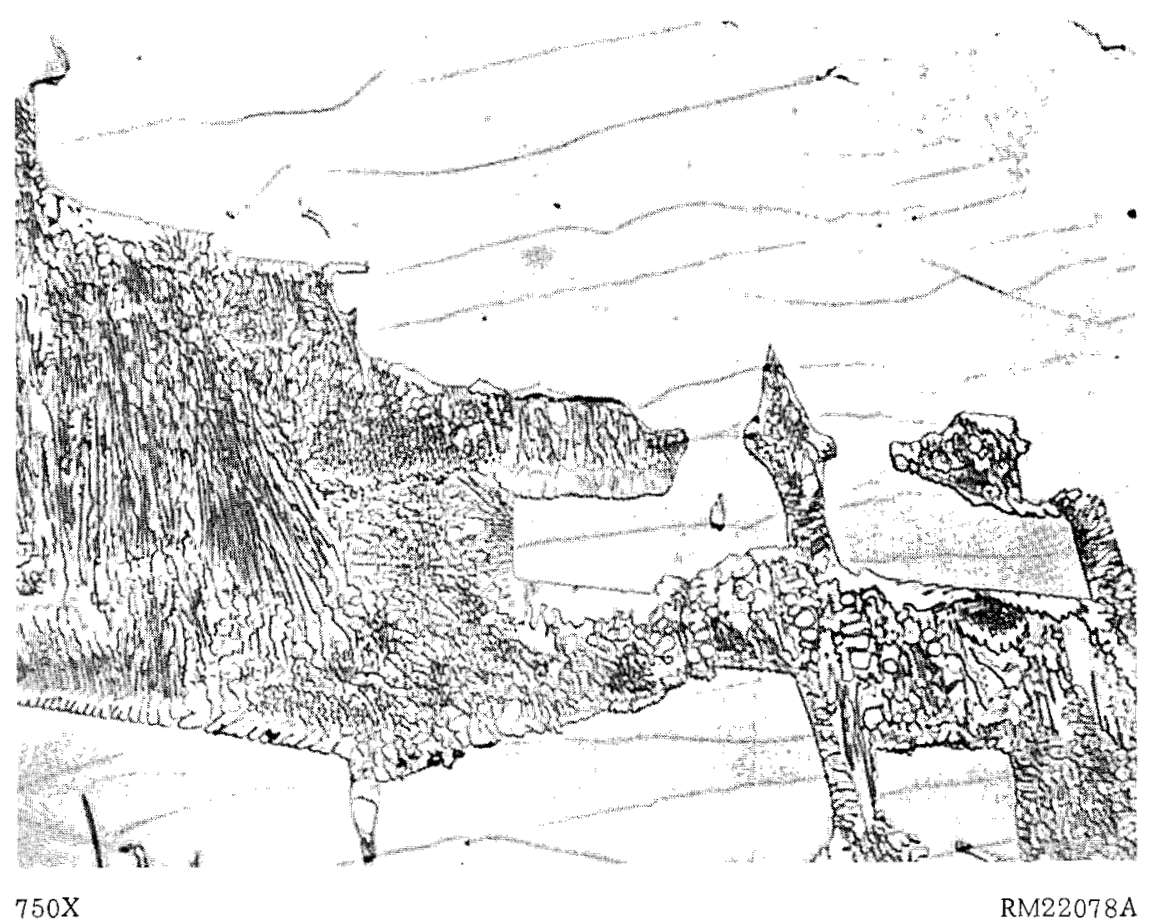

FIGURE 25. STRUCTURE OF 15 a /O URANIUM-45 a /O CARBON-40 a /O TUNGSTEN ALLOY AS HEA T-TREATED 3 HR AT $1500 \mathrm{C}$

Gray phase is $\mathrm{UWC}_{2}$; white phase is $\mathrm{W}_{2} \mathrm{C}$. 
TABLE 4. PHASES FOUND IN URANIUM-CARBONTUNGSTEN ALLOYS

\begin{tabular}{|c|c|c|c|c|}
\hline \multirow[b]{2}{*}{ Alloy } & \multicolumn{3}{|c|}{$\begin{array}{c}\text { Nominal } \\
\text { Composition, } \\
\text { a/o }\end{array}$} & \multirow{2}{*}{$\begin{array}{c}\text { Phases Identified by } \\
\text { Metallographic and } \\
\text { X-Ray Methods }\end{array}$} \\
\hline & $\overline{\mathrm{U}}$ & $\bar{C}$ & $\overline{\mathrm{W}}$ & \\
\hline$w-1$ & 15 & 45 & 40 & $\mathrm{UWC}_{2}, \mathrm{w}_{2} \mathrm{C}$ \\
\hline$w-2$ & 20 & 40 & 40 & $\mathrm{UWC}_{2}, \mathrm{~W}, \mathrm{UC}$ \\
\hline$W-3$ & 25 & 25 & 50 & $\mathrm{~W}, \mathrm{UC}$ \\
\hline
\end{tabular}

The heat-treated structure of Alloy $\mathrm{W}-2$ is shown in Figure 26. This structure shows needlelike crystals of $\mathrm{UWC}_{2}$ in a eutectic matrix of $\mathrm{UWC}_{2}$, tungsten, and UC. The eutectic composition evidently contains much more tungsten than the composition of this alloy. The heat treatment has caused a precipitate to form in the $\mathrm{UWC}_{2}$ phase, suggesting that $U \mathrm{UC}_{2}$ has a higher solubility for uranium and tungsten near the sclidus temperature than at $1500 \mathrm{C}$. This observation is in agreement with the finding of an $\mathrm{X}$-ray pattern in Alloys $\mathrm{W}-2$ and $\mathrm{W}-3$ corresponding to the low-carbon pattern of $\mathrm{UMoC}_{2}$ (Figure 2).

The heat-treated structure of Alloy $\mathrm{W}-3$ is shown in Figure 27. This structure shows coarse tungsten metal particles in a eutecticlike matrix consisting of fine particles of tungsten in a UC field. The cast structure of this alloy contained an acicular phase which was probably $U_{W} C_{2}$. It seems likely that the eutecticlike structure $i$ s the product of the peritectic reaction, $\mathrm{UWC}_{2}+\mathrm{U}$ (liquid) $=2 \mathrm{UC}+\mathrm{W}$; a reaction directly comparable to that found in the uranium-molybdenum-carbon system. On the basis of the amount of coarse tungsten present in the structure shown in Figure 27, the UC-W peritectic or eutectic reaction evidently occurs near 40 a/o carbon, 38 a/o uranium, and 22 a/o tungsten.

\section{Ternary Section}

The data obtained above are in agreement in all important particulars with the ternary section reported by Rudy, et al. (25) A ternary section at $1500 \mathrm{C}$ is shown as Figure 28.

\section{YTTRIUM-CARBON SYSTEM}

\section{Background}

At least two, and probably three, carbides exist in the binary yttrium-carbon system. The lowest carbon phase has a wide range of existence from $\mathrm{YC}_{0.25}$ to 


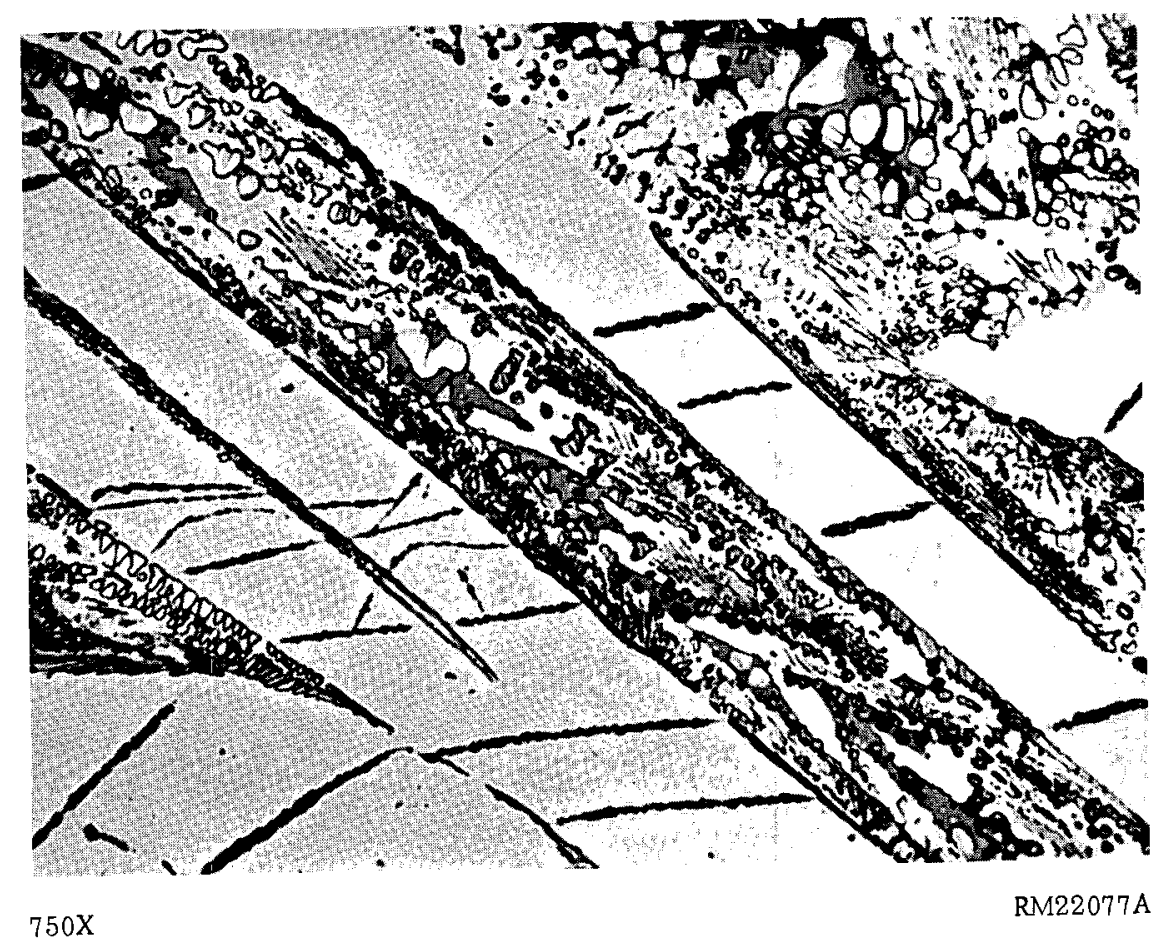

FIGURE 26. STRUCTURE OF 20 a $/ 0$ URANIUM-40 a $/ 0$ CARBON-40 a /o TUNGSTEN ALLOY AS HEAT TREATED 3 HR AT $1500 \mathrm{C}$

Major white phase is $\mathrm{UWC}_{2}$. Globular white phase is tungsten metal. Dark gray phase is UC.

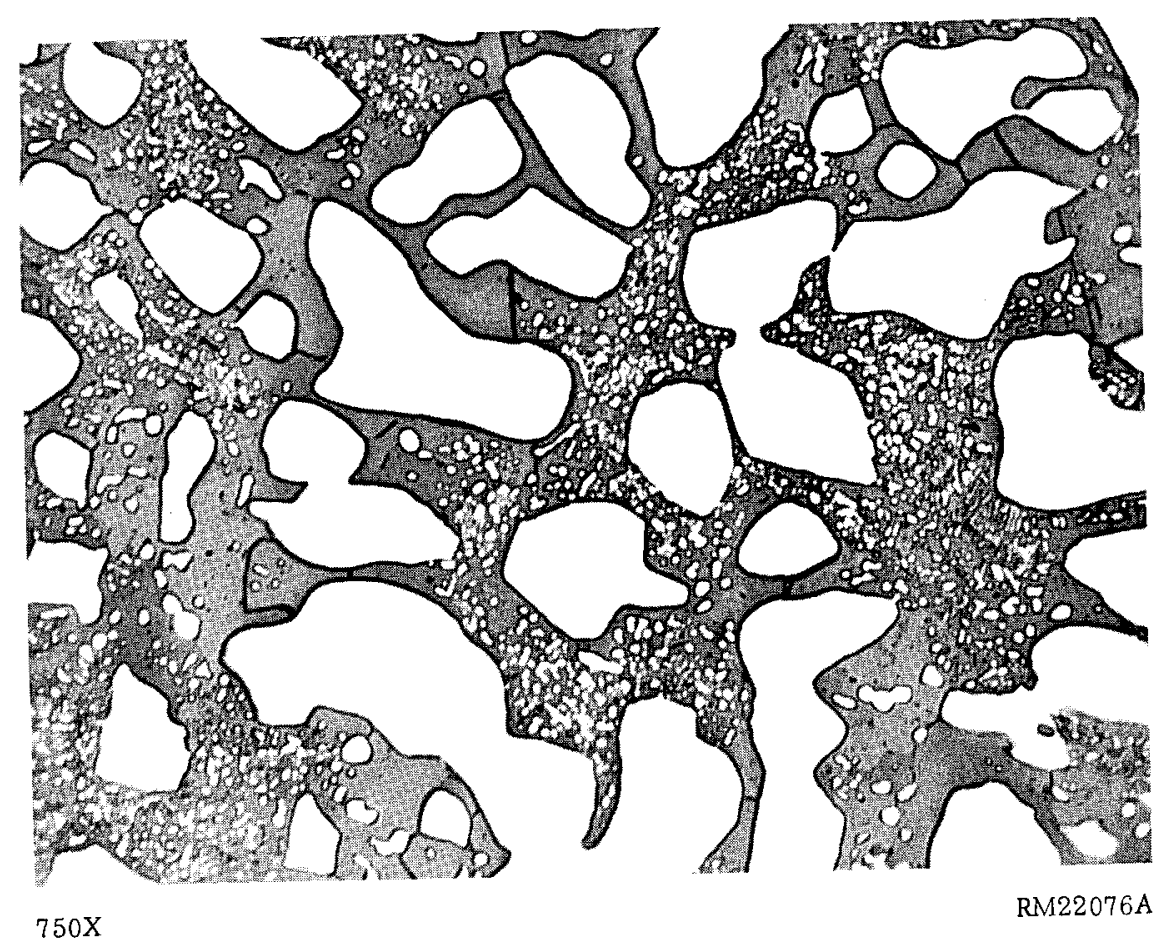

FIGURE 27. STRUCTURE OF 25 a /O URANIUM-25 a /o CARBON-50 a /o TUNGSTEN ALLOY AS HEAT TREATED 3 HR AT $1500 \mathrm{C}$

White phase is tungsten metal. Dark gray phase is UC. 


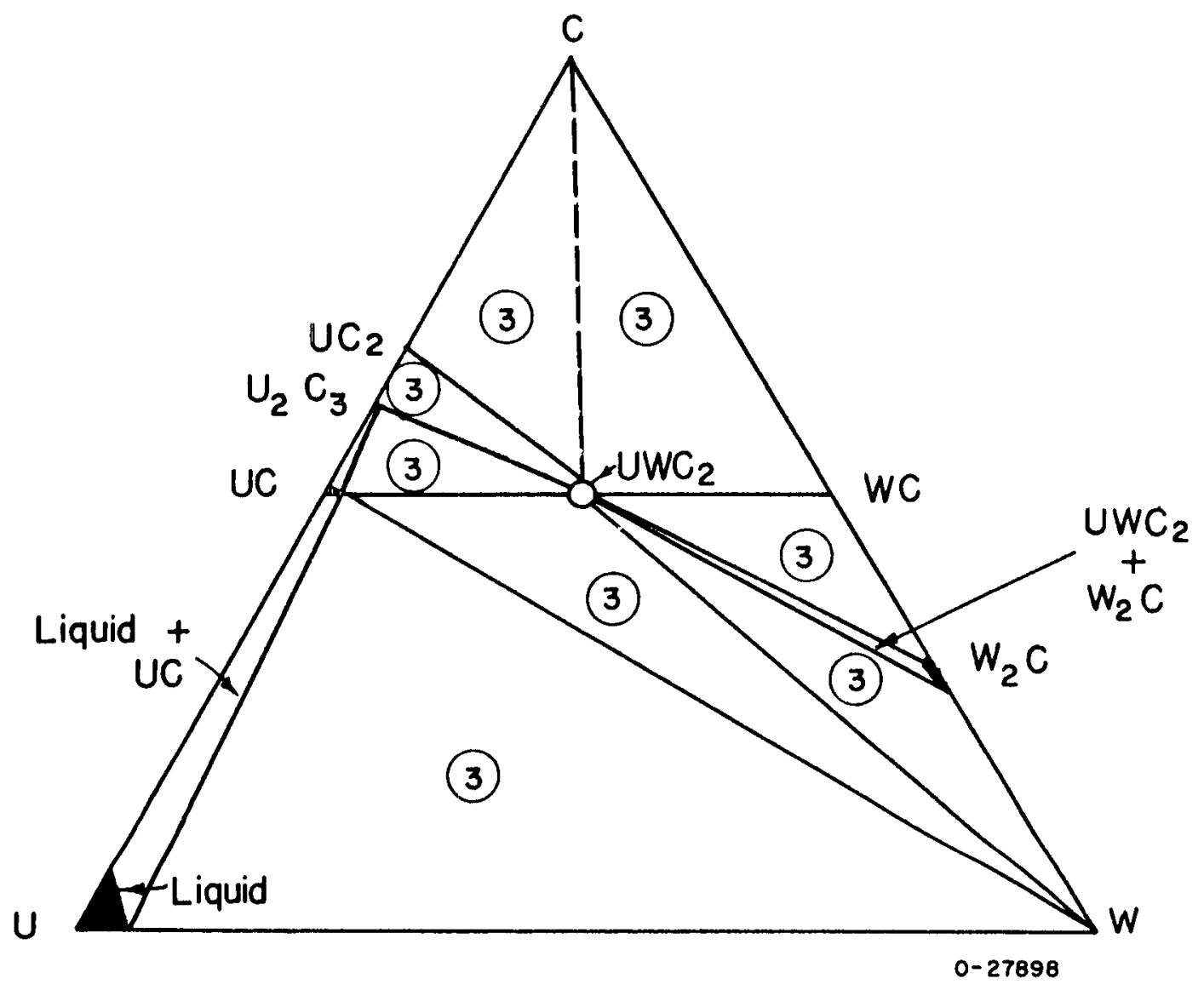

FIGURE 28. URANIUM-CARBON-TUNGSTEN SYSTEM AT $1500 \mathrm{C}$ 
$\mathrm{YC}_{0.40}$ (20 to 29 a/o carbon). (26) An alloy containing $12 \mathrm{w} / \mathrm{o}(50 \mathrm{a} / \mathrm{o}$ ) carbon had a melting point of $1950 \mathrm{C}$ and a hardness of $120 \mathrm{~kg}$ per $\mathrm{mm}^{2}$. (27) Above $1900 \mathrm{C}$, Y C melted and decomposed, forming volatile yttrium and a liquid rich in carbon. (27)

Yttrium dicarbide has a melting point over 2300 C. (28)

\section{Crystallography}

$\mathrm{YC}$ is face-centered cubic (carbon-deficient $\mathrm{NaCl}$ structure), having four yttrium atoms per unit cell, with $a=5.10 \mathrm{~A}$ in equilibrium with yttrium and $a=5.12 \mathrm{~A}$ in equilibrium with $\mathrm{YC}_{2}$. Density is $5.5 \mathrm{~g}$ per $\mathrm{cm}^{3}$.

$\mathrm{Y}_{2} \mathrm{C}_{3}$ exhibits low symmetry, and is not isostructural with $\mathrm{Pu}_{2} \mathrm{C}_{3}$. (26)

$\mathrm{YC}_{2}$ is tetragonal $\left(\mathrm{CaC}_{2}\right.$ type), having two molecules per unit cell, with $\mathrm{a}=3.66$ and $\mathrm{c}=6.17 \mathrm{~A}$. Density is $4.53 \mathrm{~g}$ per $\mathrm{cm}^{3}$. At temperatures of $1500 \mathrm{C}$ and above, $\mathrm{YC}_{2}$ has an allotropic modification which is probably isostructural with $\mathrm{UC}_{2}$; $i$. e. facecentered cubic.

\section{Experimental Results}

The five yttrium-carbon alloys listed in Table 5 were prepared by arc melting. Analyses obtained on three of the alloys produced results checking the nominal compositions within 2 a/o. The structure of Alloy BY-1 is shown in Figure 29. This photomicrograph shows a single phase identified by X-ray examination as tetragonal $\mathrm{YC}_{2}$. The needles are indicative of a solid-state martensitelike phase transformation, presumably from a congruently melting, high-temperature, cubic allotrope represented by the equiaxed structure, to the tetragonal structure present at room temperature. This alloy had a hardness of $410 \mathrm{~kg}$ per $\mathrm{mm}^{2}$. This structure was not materially altered by a heat treatment of $3 \mathrm{hr}$ at $1500 \mathrm{C}$, showing that the allotropic transformation temperature is below $1500 \mathrm{C}$.

\section{TABLE 5. PHASES FOUND IN YTTRIUM-CARBON ALLOYS}

\begin{tabular}{|c|c|c|c|}
\hline Alloy & $\begin{array}{c}\text { Nominal } \\
\text { Carbon Content, } \\
\text { a/o }\end{array}$ & $\begin{array}{l}\text { Phases Identified } \\
\text { by Metallographic } \\
\text { and X-ray Methods }\end{array}$ & $\begin{array}{c}\text { Lattice Parameter } \\
\text { of YC Phase, } \\
\text { A }\end{array}$ \\
\hline $\mathrm{BY}-1$ & 66 & $\mathrm{YC}_{2}$ (tetragonal) & -- \\
\hline$B Y-2$ & 60 & $\mathrm{YC}_{2}, \mathrm{YC}$ & -- \\
\hline $\mathrm{BY}-3$ & $50(a)$ & $\mathrm{YC}, \mathrm{YC}_{2}$ & 5.12 \\
\hline $\mathrm{BY}-4$ & $35(b)$ & YC, yttrium & 5.10 \\
\hline $\mathrm{BY}-5$ & $20^{(c)}$ & YC, yttrium & 5.10 \\
\hline
\end{tabular}

(a) Chemical analysis showed 50 a/o carbon.

(b) Chemical analysis showed 37 a/o carbon.

(c) Chemical analysis showed 21 a/o carbon. 
After annealing for $3 \mathrm{hr}$ at $1500 \mathrm{C}$, Alloy BY-2 in Table 5 was identified as largely $\mathrm{YC}_{2}$ plus some $\mathrm{YC}$. This result shows that, if $\mathrm{Y}_{2} \mathrm{C}_{3}$ exists, it probably forms by peritectoid reaction at a lower temperature.

Alloy BY -3 had a hardness of $580 \mathrm{~kg}$ per $\mathrm{mm}^{2}$, exhibited a submetallic luster similar to that of mill scale $\left(\mathrm{Fe}_{3} \mathrm{O}_{4}\right)$, and reacted readily with water to form acetylene and probably other gases. The microstructure of the alloy after annealing for $3 \mathrm{hr}$ at $1500 \mathrm{C}$ is shown in Figure 30. This photomicrograph shows a white phase identified as tetragonal $\mathrm{YC}_{2}$. A needlelike substructure within these particles (not developed in this photomicrograph) confirmed that the $\mathrm{YC}_{2}$ was above its allotropic transformation temperature at $1500 \mathrm{C}$. The gray, major phase present is $\mathrm{YC}$ having a lattice parameter of 5.12A. Clearly YC does not exist at its stoichiometric composition, and this photomicrograph showing about 25 volume per cent $\mathrm{YC}_{2}$ in an alloy at 50 a/o carbon suggests that the upper limit of the range of existence of $\mathrm{YC}$ is about 40 a/o carbon.

Alloy BY-4 in Table 5 is shown in Figure 31 after annealing for $3 \mathrm{hr}$ at $1500 \mathrm{C}$. This microstructure shows spheroidized islands of $\mathrm{YC}$ in a eutectic matrix. This; microstructure confirms that the melting point of $\mathrm{YC}$ is above $1500 \mathrm{C}$ and that a eutectic, melting below $1500 \mathrm{C}$, exists between $\mathrm{YC}$ and yttrium metal. This alloy, containing about 35 a/o carbon and showing a structure containing about 15 volume per cent yttrium metal, suggests that the lower limit of the range of existence of $\mathrm{YC}$ is alsio about 40 a/o carbon. A lattice parameter of $5.10 \mathrm{~A}$ was obtained for the $\mathrm{YC}$ in this alloy, so YC must have a slight range of homogeneity.

The cast structure of the above alloy showed dendrites of YC plus other phases which could not be positively identified. The presence of $\mathrm{YC}_{2}$ was suggested by some of the $\mathrm{X}$-ray lines; and the microstructure showed signs of reactions between the phases during cooling, indicating that $\mathrm{YC}$ forms by peritectic reaction and that the critical composition is near but below 35 a/o carbon.

The cast structure of Alloy BY-5 in Table 5 also showed about 30 volume per cent primary dendrites of $\mathrm{YC}$ in a eutectic matrix. This structure, shown in Figure 32, locates the eutectic composition near 15 a/o carbon. When this alloy was annealed at $1500 \mathrm{C}$, a structure indicating incipient or partial melting resulted, showing that "he eutectic temperature is very near $1500 \mathrm{C}$. The yttrium metal in the alloy agglomerated into a massive, irregular network. A small amount of an oriented (Widmanstätte: ) precipitate formed in the yttrium, showing that yttrium dissolves some carbon, perhaps up to 2 a/o, at $1500 \mathrm{C}$.

\section{Binary Constitutional Diagram}

A binary constitutional diagram for the yttrium-carbon system which is consistent with the available data is shown as Figure 33. $\mathrm{YC}_{2}$ is presumed to have a congruent melting point and, therefore, a eutectic must exist between it and graphite. The black triangle on the $\mathrm{YC}_{2}$ composition at about $1300 \mathrm{C}$ indicates an allotropic transformation at an unknown temperature below $1500 \mathrm{C}$. The data on $\mathrm{Y}_{2} \mathrm{C}_{3}$ are not clear, and it is indicated as forming by a peritectoid reaction below $1500 \mathrm{C}$. 


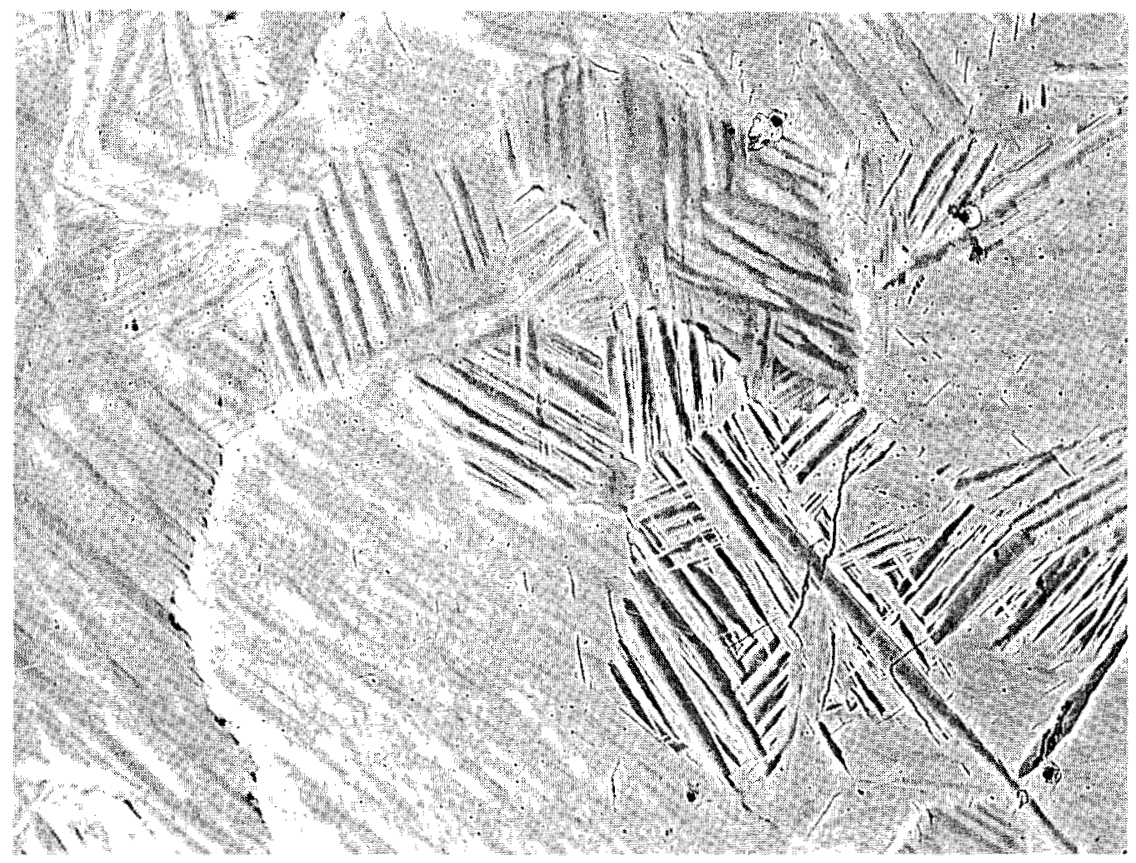

$100 \mathrm{X}$

RM22836

FIGURE 29. AS-CAST STRUCTURE OF 33 a $/ 0$ YTTRIUM-66 a $/ 0$ CARBON ALLOY

Martensitelike needles of tetragonal $\mathrm{YC}_{2}$ formed within the equiaxed grain structure of a presumed high-temperature, cubic allotrope of $\mathrm{YC}_{2}$.

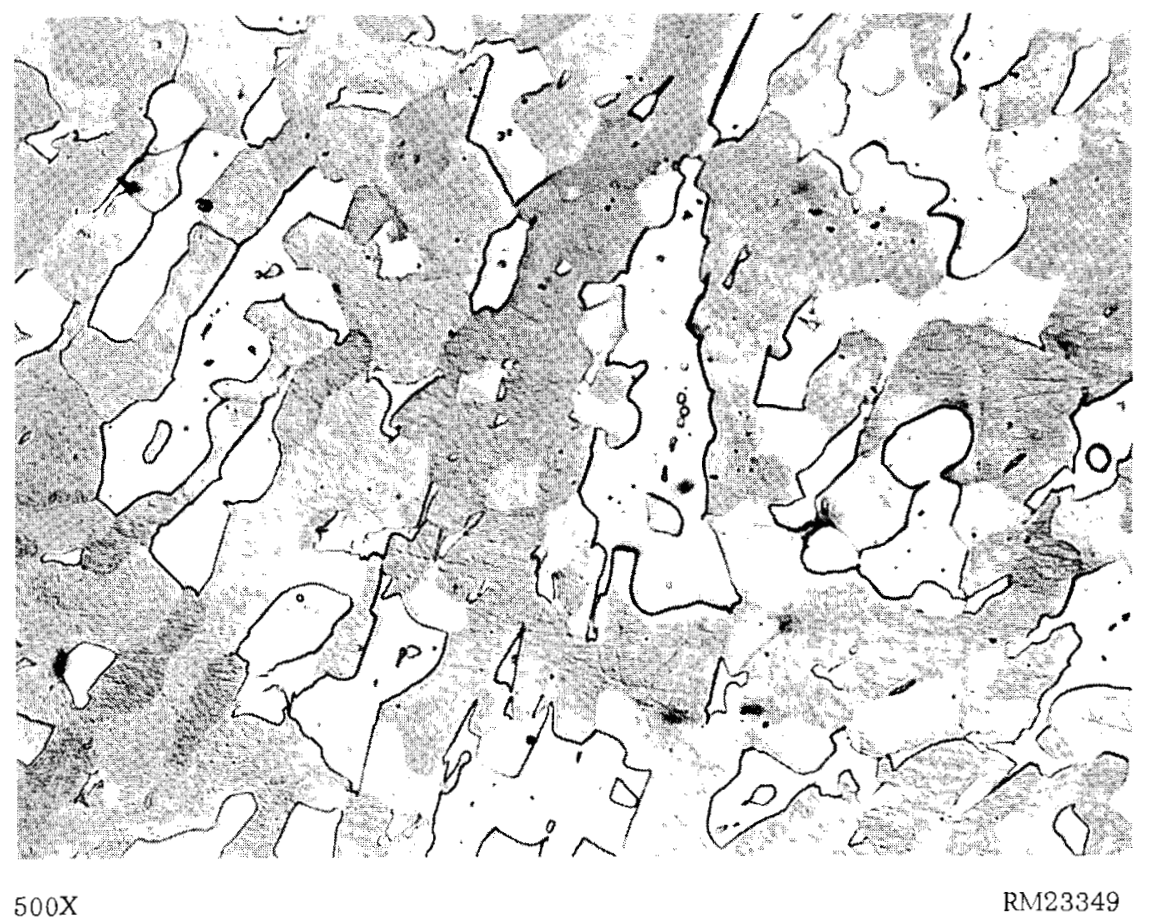

FIGURE 30. STRUCTURE OF A 50 a /O YTTRIUM-50 a /o CARBON ALLOY, AS ANNEALED 3 HR AT $1500 \mathrm{C}$

About 25 volume per cent of tetragonal $\mathrm{YC}_{2}$ appears in a gray mottled matrix of YC. 


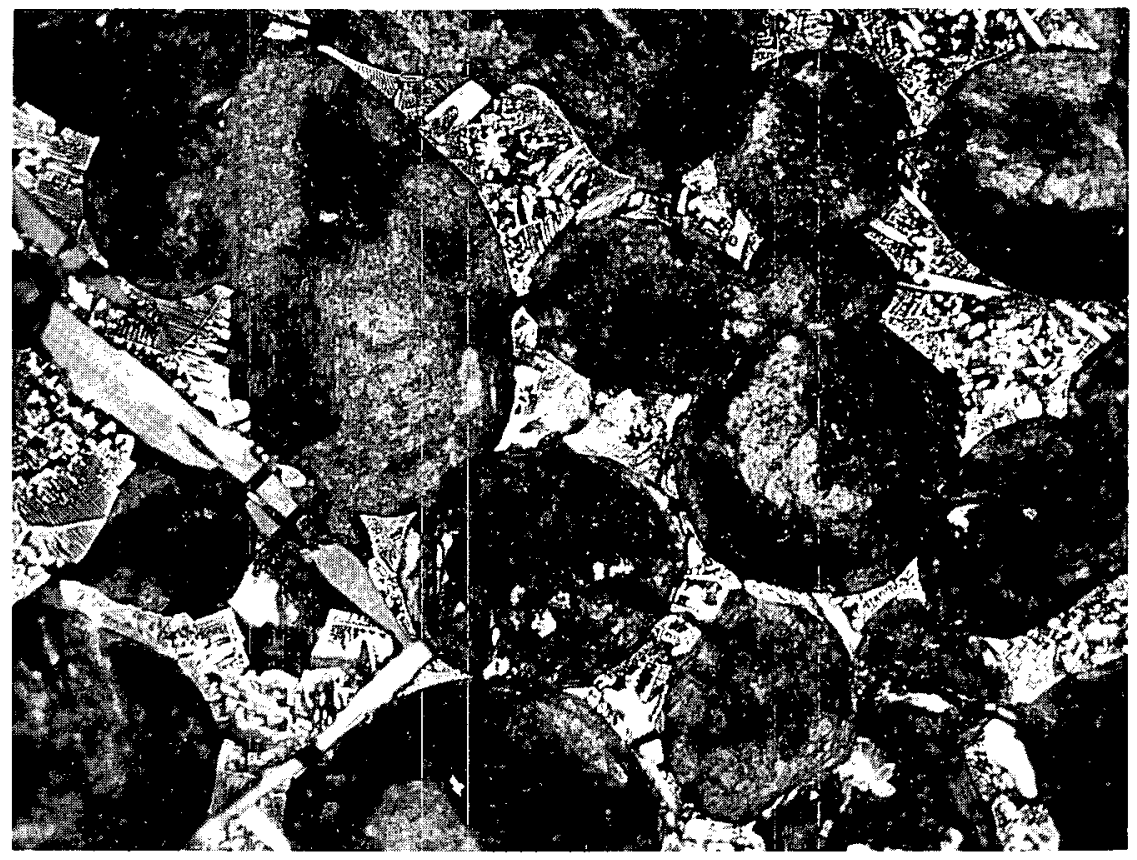

$500 \mathrm{X}$

RM24472

FIGURE 31. STRUCTURE OF 65 a $/ 0$ YTTRIUM -35 a $/ 0$ CARBON ALLOY, AS ANNEALED 3 HR AT $1500 \mathrm{C}$

Black spheroids of $\mathrm{YC}$ are present in a eutectic matrix consisting of $\mathrm{YC}$ and yttrium metal.

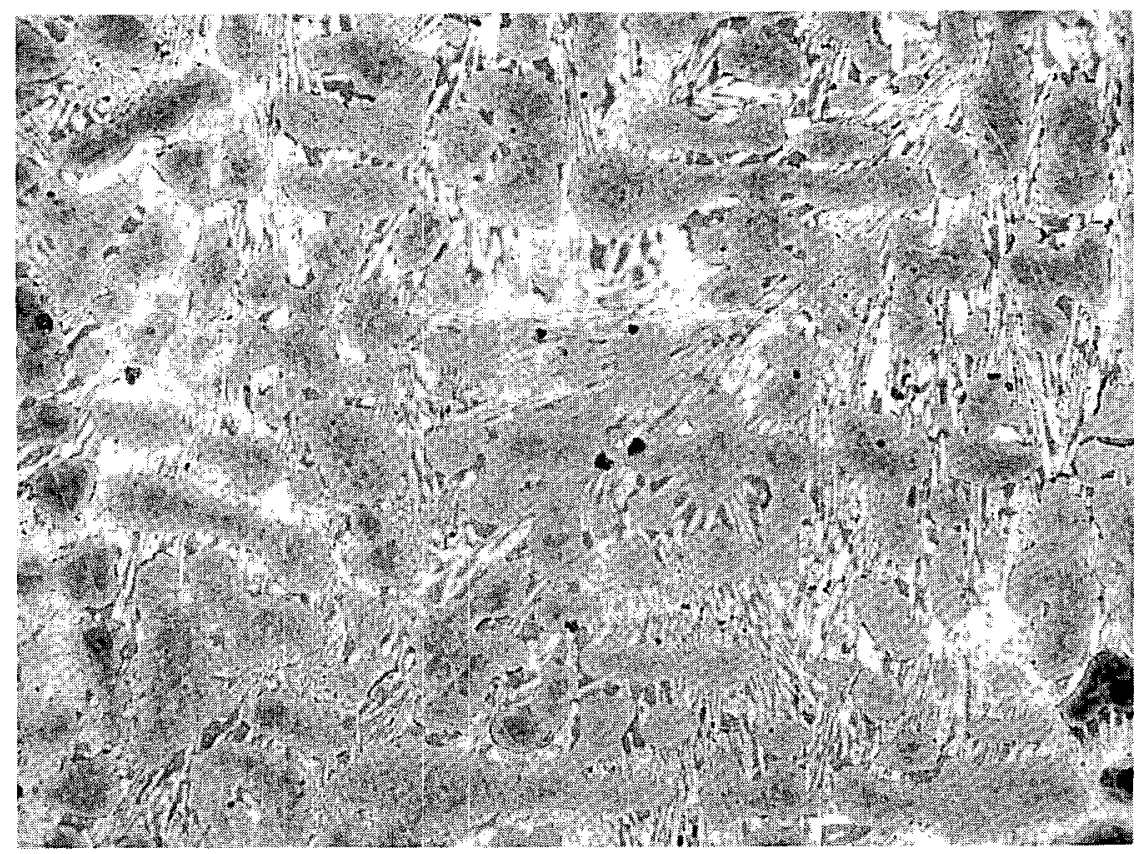

FIGURE 32. AS-CAST STRUCTURE OF 80 a $/ 0$ YTTRIUM -20 a $/ 0$ CARBON ALLOY

Primary dendrites of $\mathrm{YC}$ are visible in a yttrium - $\mathrm{YC}$ eutectic matrix. 


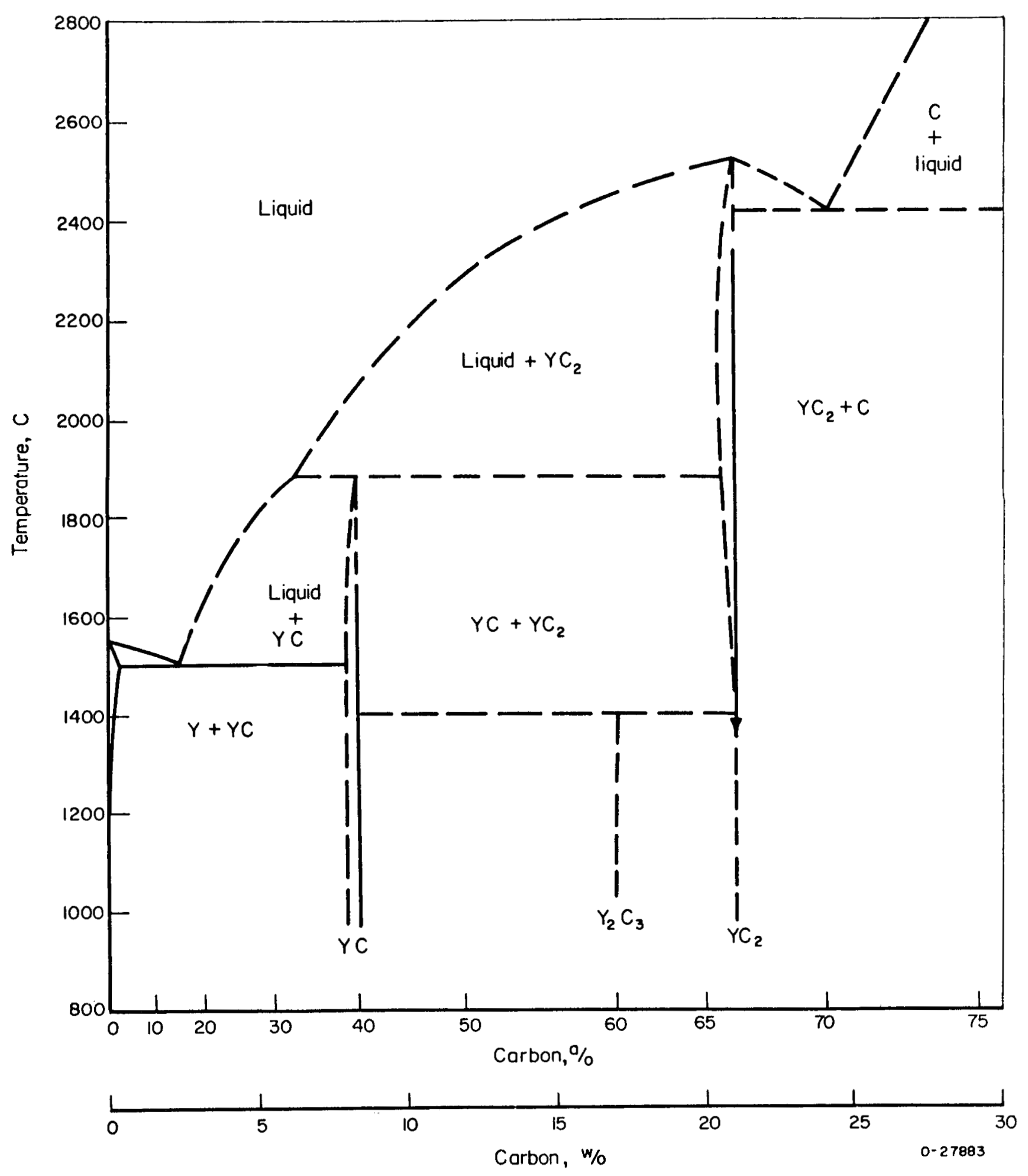

FIGURE 33. YTTRIUM-CARBON CONSTITUTIONAL DIAGRAM 


\section{Experimental Results}

The alloys listed in Table 6 were prepared in the form of $50-\mathrm{g}$ buttons by arc melting the elemental materials. The cast structure of Alloy $Y-1$ is shown in Figure 34. This structure shows primary, gray dendrities of YC, brilliant white spheroids of uranium metal, and a eutectic containing primarily yttrium metal and YC. The structure of the same alloy after annealing for $3 \mathrm{hr}$ at $1500 \mathrm{C}$ is shown in Figiure 35. The spheroids of uranium show a cored appearance which suggests that liquid uranium dissolves appreciable yttrium at $1500 \mathrm{C}$. The yttrium has formed an intergranula $\mathrm{r}$ network. A trace of a Widmanstätten precipitate may be seen in the yttrium, corıfirming the finding that appreciable carbon is soluble in yttrium at $1500 \mathrm{C}$. The markings on the $\mathrm{YC}$ are the result of oxidation during specimen preparation; this stage of oxidation represents an intermediate condition between that shown in Figure 30, where only very faint marks are visible on the YC, to that shown in Figure 31, where the oxidation products have formed a continuous layer of loose powder on the surface of the YC particles.

\section{TABLE 6. PHASES FOUND IN URANIUM-CARBON-YTTRIUM ALLOYS}

\begin{tabular}{|c|c|c|c|c|c|}
\hline \multirow[b]{2}{*}{ Alloy } & \multicolumn{3}{|c|}{$\begin{array}{c}\text { Nominal Composition, } \\
\text { a/o }\end{array}$} & \multirow{2}{*}{$\begin{array}{l}\text { Phases Identified } \\
\text { by Metallographic } \\
\text { and X-ray Methods }\end{array}$} & \multirow{2}{*}{$\begin{array}{c}\text { Lattice Parameter } \\
\text { of FCC (U, Y)C } \\
\text { Phase, A }\end{array}$} \\
\hline & $\overline{\mathrm{U}}$ & $\mathrm{C}$ & $\mathrm{Y}$ & & \\
\hline$Y-1$ & 10 & 20 & 70 & YC, yttrium, uranium & 5.10 \\
\hline$Y-2$ & 25 & 25 & $50^{(a)}$ & YC, uranium, yttrium & $5.04,5.11$ \\
\hline$Y-3$ & 40 & 25 & 35 & $(Y, U) C$, uranium & 5.04 \\
\hline$Y-4$ & 25 & 35 & 40 & $(\mathrm{Y}, \mathrm{U}) \mathrm{C}$, uranium & $5.02,5.04$ \\
\hline$Y-5$ & 20 & 40 & 40 & $(\mathrm{Y}, \mathrm{U}) \mathrm{C}$, uranium & $5.01,5.02$ \\
\hline$Y-6$ & 33 & 33 & 33 & $(\mathrm{Y}, \mathrm{U}) \mathrm{C}$, uranium & 5.00 \\
\hline$Y-7$ & 45 & 35 & 20 & $(\mathrm{U}, \mathrm{Y}) \mathrm{C}$, uranium & 5.00 \\
\hline$Y-8$ & 25 & 50 & 25 & $(\mathrm{U}, \mathrm{Y}) \mathrm{C}, \mathrm{YC}_{2}$ & 4.99 \\
\hline$Y-9$ & 42 & 50 & 8 & $(\mathrm{U}, \mathrm{Y}) \mathrm{C}, \mathrm{YC}_{2}$ & -- \\
\hline$Y-10$ & 30 & 60 & 10 & $(\mathrm{U}, \mathrm{Y}) \mathrm{C}_{2}, \mathrm{UC}$ & $4.96,4.96$ \\
\hline
\end{tabular}

(a) Chemical analysis showed 27 a/o carbon, 25 a/o uranium.

The appearance of large amounts of uncombined uranium metal in this alloy containing only 10 a/o uranium shows that yttrium displaces uranium from uranium carbide and that the carbide-rich corner of the three-phase field, monocarbide-uraniumyttrium, occurs at a composition where YC contains little, if any, uranium in solution.

Alloy $Y-2$ in Table 6 showed structures which were qualitatively identical, but quantitatively different from the first alloy. Much more metallic uranium and mich less metallic yttrium were observed.

See the preceding section on the ytrium-carbon system for available background and crystallography data. 
Alloys $\mathrm{Y}-3$ through $\mathrm{Y}-7$ all contained a face-centered-cubic carbide and uranium metal, both as cast and after annealing at $1500 \mathrm{C}$. The face-entered-cubic carbide showed lattice parameters varying continuously, as noted in Table 6, and this was identified as a continuous solid solution between $\mathrm{UC}$ and $\mathrm{YC}$; i.e. (U, Y)C. The structures were dendritic as cast, but became equiaxed when annealed at $1500 \mathrm{C}$. A drastic coarsening which occurred during annealing was attributed to the presence of liquid uranium.

Alloys $\mathrm{Y}-8$ through $\mathrm{Y}-10$ in Table 6 , containing 50 and 60 a/o carbon, were dendritic as cast, and did not become equiaxed when annealed for $3 \mathrm{hr}$ at $1500 \mathrm{C}$. The structure of Alloy $Y-8,25$ a/o uranium-50 a/o carbon- 25 a/o yttrium after annealing at $1500 \mathrm{C}$ is shown in Figure 36. This structure consists of dendritic (U, Y)C plus an interdendritic material identified as containing $\mathrm{YC}_{2}$. This structure shows that at this composition, (U, Y)C contains less than 50 a/o carbon. Alloy $Y-9,42$ a/o uranium$50 \mathrm{a} / 0$ carbon-8 a/o yttrium, also contained a small amount of $\mathrm{YC}_{2}$, suggesting that the $(U, Y) C$ solid solution may contain less than 50 a/o carbon even at this low yttrium content.

Alloy $\mathrm{Y}-10$ contained a tetragonal phase having lattice parameters of $a=3.54$ and $c=6.12 \mathrm{~A}$. Since the se are intermediate to those of $\mathrm{UC}_{2}(a=3.51, c=5.98 \mathrm{~A})$ and those of $\mathrm{YC}_{2}(\mathrm{a}=3.66, \mathrm{c}=6.17 \mathrm{~A})$, it seems likely that a complete series of solid solutions exists between $\mathrm{UC}_{2}$ and $\mathrm{YC}_{2}$. The cast and annealed structures of this alloy are shown in Figure 37. The cast structure is believed to show mainly the (U, Y) $\mathrm{C}_{2}$ phase, which is severely cored with respect to metal atoms and appreciably substoichiometric. The entire structure has apparently undergone the martensitelike transformation to the tetragonal allotrope. An appreciable amount of essentially pure $\mathrm{UC}$ is present in the alloy, suggesting that pure $\mathrm{YC}_{2}$ has virtually no solubility for $(U, Y) C$. The annealed structure is believed to show the high-yttrium cores of the $(\mathrm{U}, \mathrm{Y}) \mathrm{C}_{2}$ phase essentially unchanged by the heat treatment. The lower carbon, higher uranium portions of the (U, Y) $\mathrm{C}_{2}$ phase have decomposed into a eutectoid structure, presumably by precipitating additional UC. The lattice parameters for the $(Y, U) C_{2}$ solid solution given above were obtained on the annealed alloy, so it seems likely that the high-yttrium dendrite cores contain at least 15 a/o yttrium. Thus, the range of homogeneity with respect to carbon content of (U, Y) $\mathrm{C}_{2}$ containing 15 a/o yttrium or more is quite small at temperatures above $1500 \mathrm{C}$. Below 10 a/o yttrium the range of homogeneity of $(U, Y) C_{2}$ must approach that of $\mathrm{UC}_{2}$.

\section{Ternary Section}

The ternary phase relationships derived from the above data are shown as a ternary isothermal section at $1500 \mathrm{C}$ in Figure 38.

\section{ACKNOW LEDGMENT}

The X-ray work required as part of these studies was performed by D. I. Phalen. 


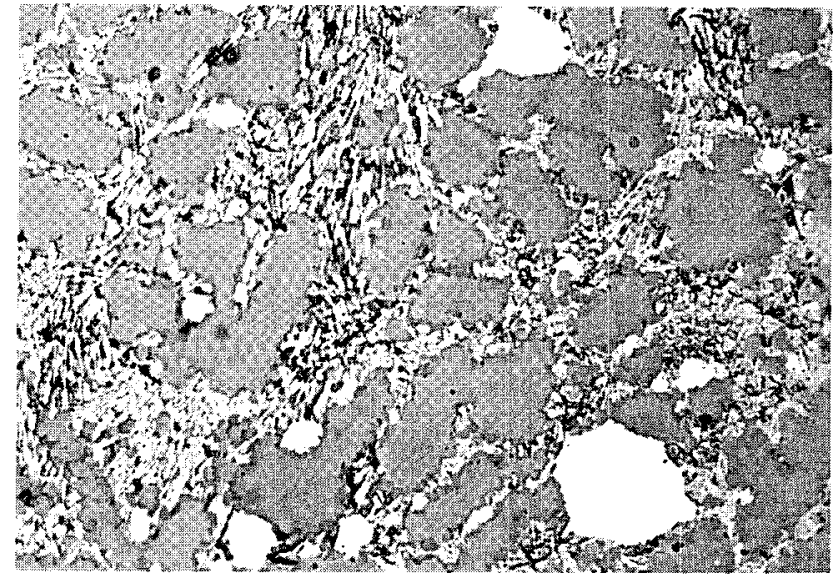

$500 \mathrm{X}$

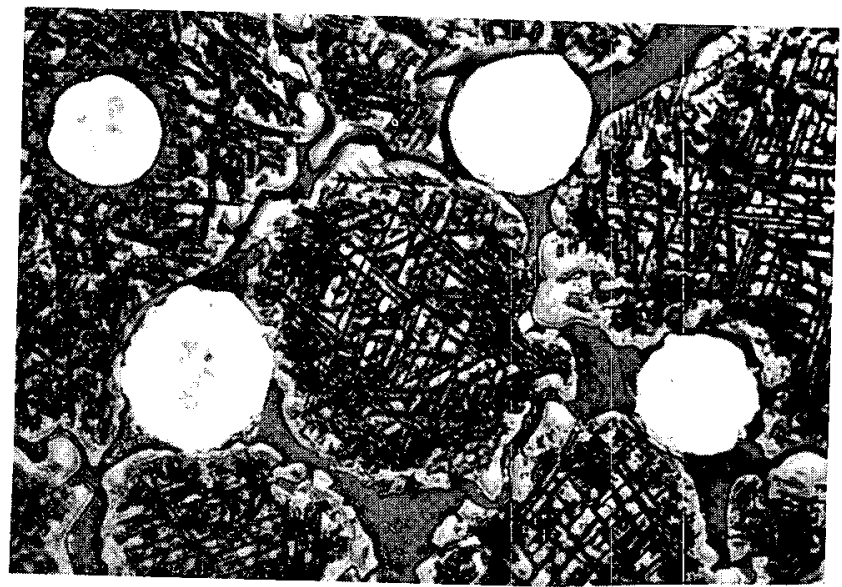

$500 \mathrm{X}$

RM24473

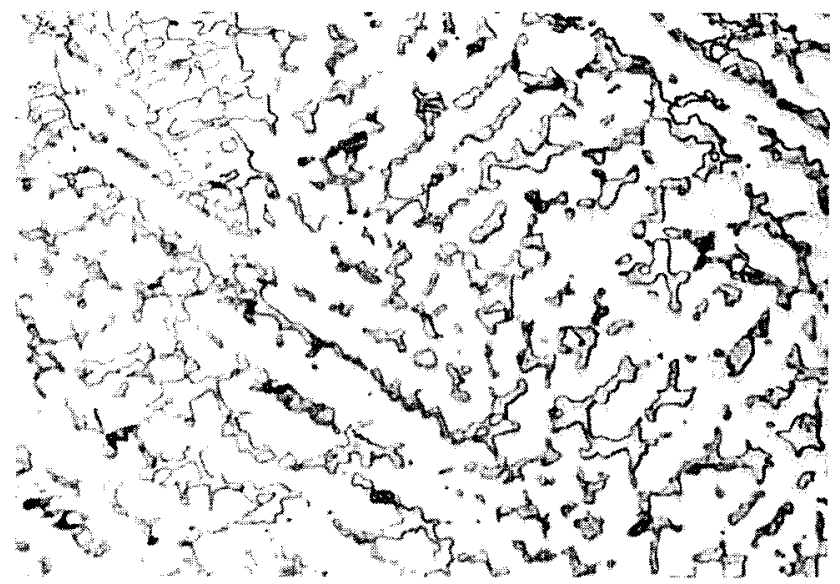

$500 \mathrm{X}$

RM23352
FIGURE 34. AS-CAST STRUCTURE OF A 10 a $/ 0$ URANIUM -20 a $/ 0$ CARBON -70 a $/ 0$ YTTRIUM ALLOY

Gray dendrites of YC, bright white spheroids of uranium, and a eutectic of yttrium and $\mathrm{YC}$ are shown.

FIGURE 35, STRUCTURE OF A 10 a $\%$ URANIUM 20 a /O CARBON-70 a /O YTTRIUM ALLOY ANNEALED 3 HR AT $1500 \mathrm{C}$

Irregular crosspatched particles of $\mathrm{YC}$, bright white spheroids of uranium, and matte gray intergranular network of yttrium containing a trace amount of a Widmanstätten precipitate are visible.

FIGURE 36. STRUCTURE OF A 25 a \% URANIUM50 a / O CARBON-25 a / Y YTTRIUM ALLOY ANNEALED 3 HR AT $1500 \mathrm{C}$ Dendrites of $(U, Y) C$ plus an interdendritic material containing $\mathrm{YC}_{2}$ are evident. 


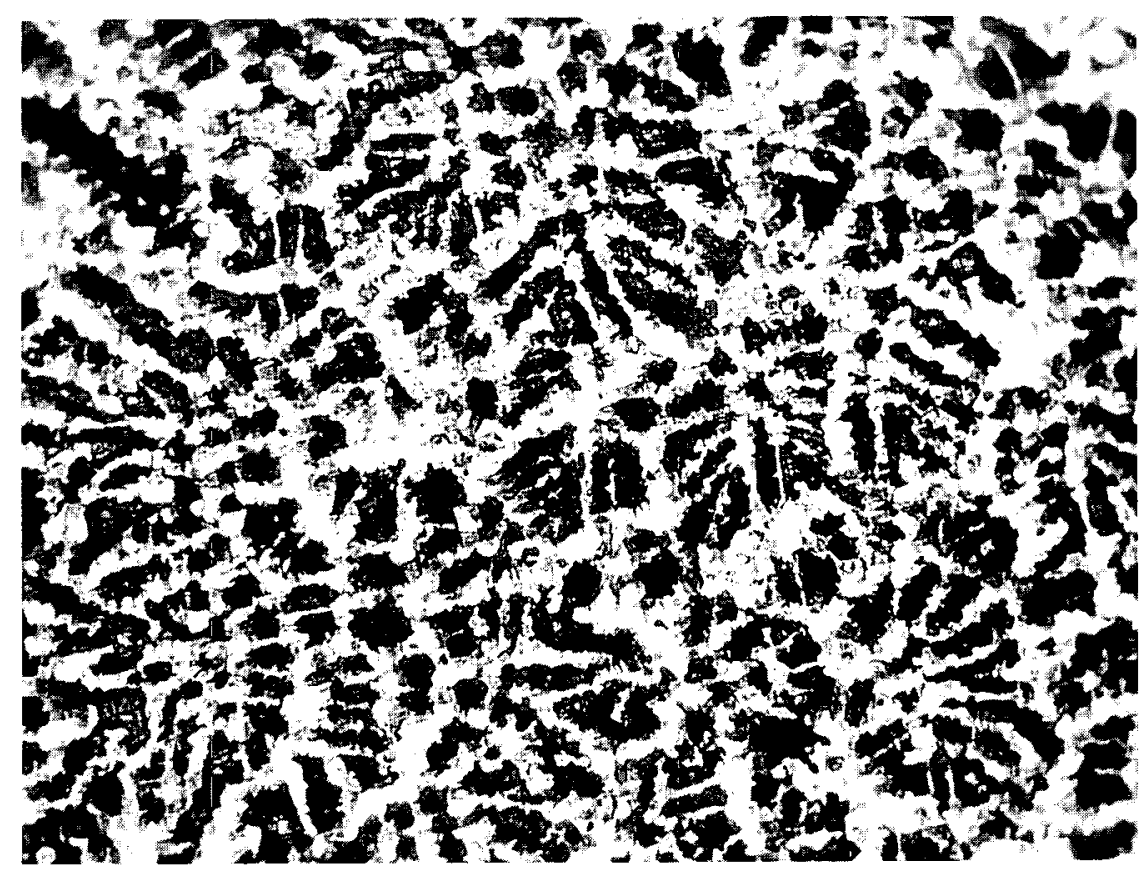

$500 \mathrm{X}$

As Cast

RM22852

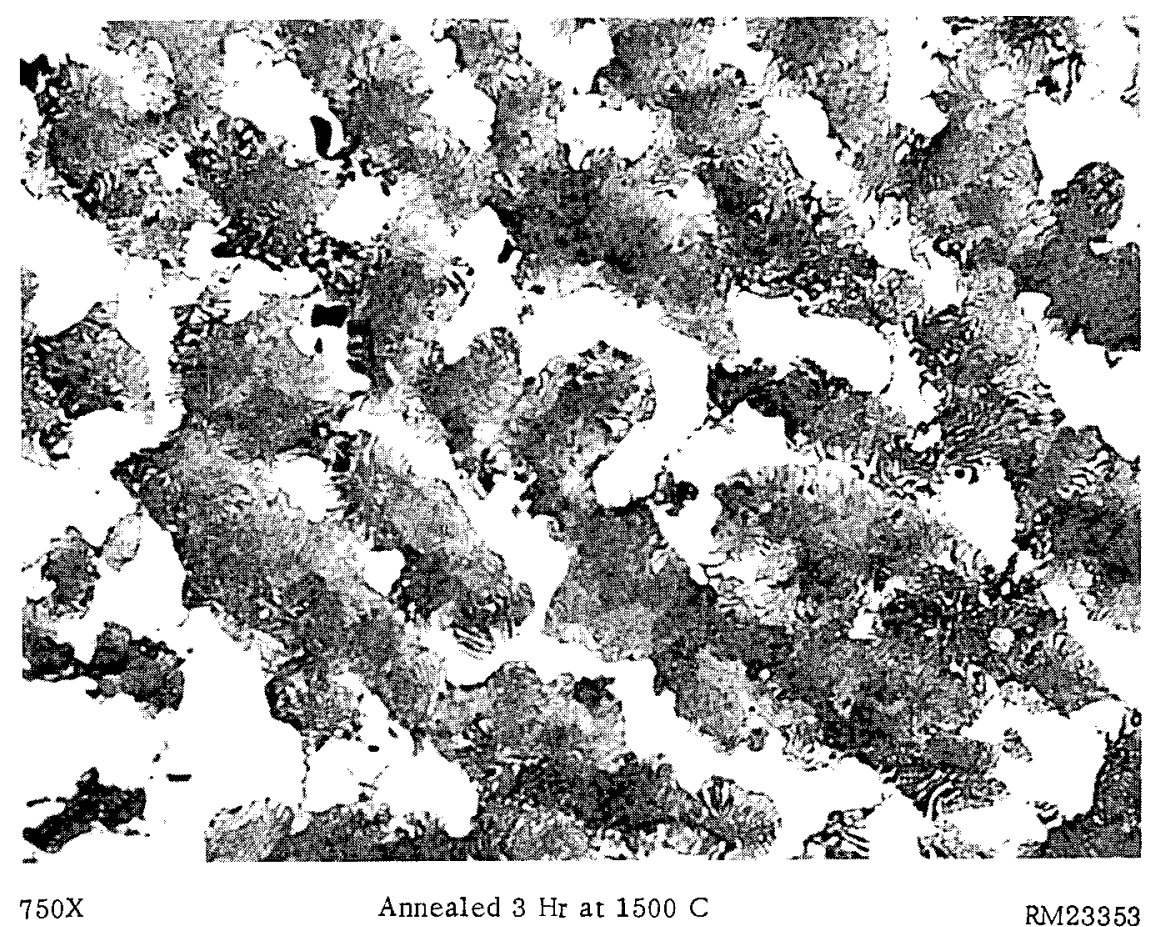

FIGURE 37. STRUCTURES OF 30 a $/ 0$ URANIUM-60 a $/ 0$ CARBON -10 a $/ 0$ YTTRIUM ALLOY

Cast structure shows cored (U, Y) $\mathrm{C}_{2}$ plus some UC. Annealed structure shows residual, high-yttrium cores of the $(\mathrm{U}, \mathrm{Y}) \mathrm{C}_{2}$ plus eutectoidlike decomposition product of the low-yttrium portions of the $(\mathrm{U}, \mathrm{Y}) \mathrm{C}_{2}$. 


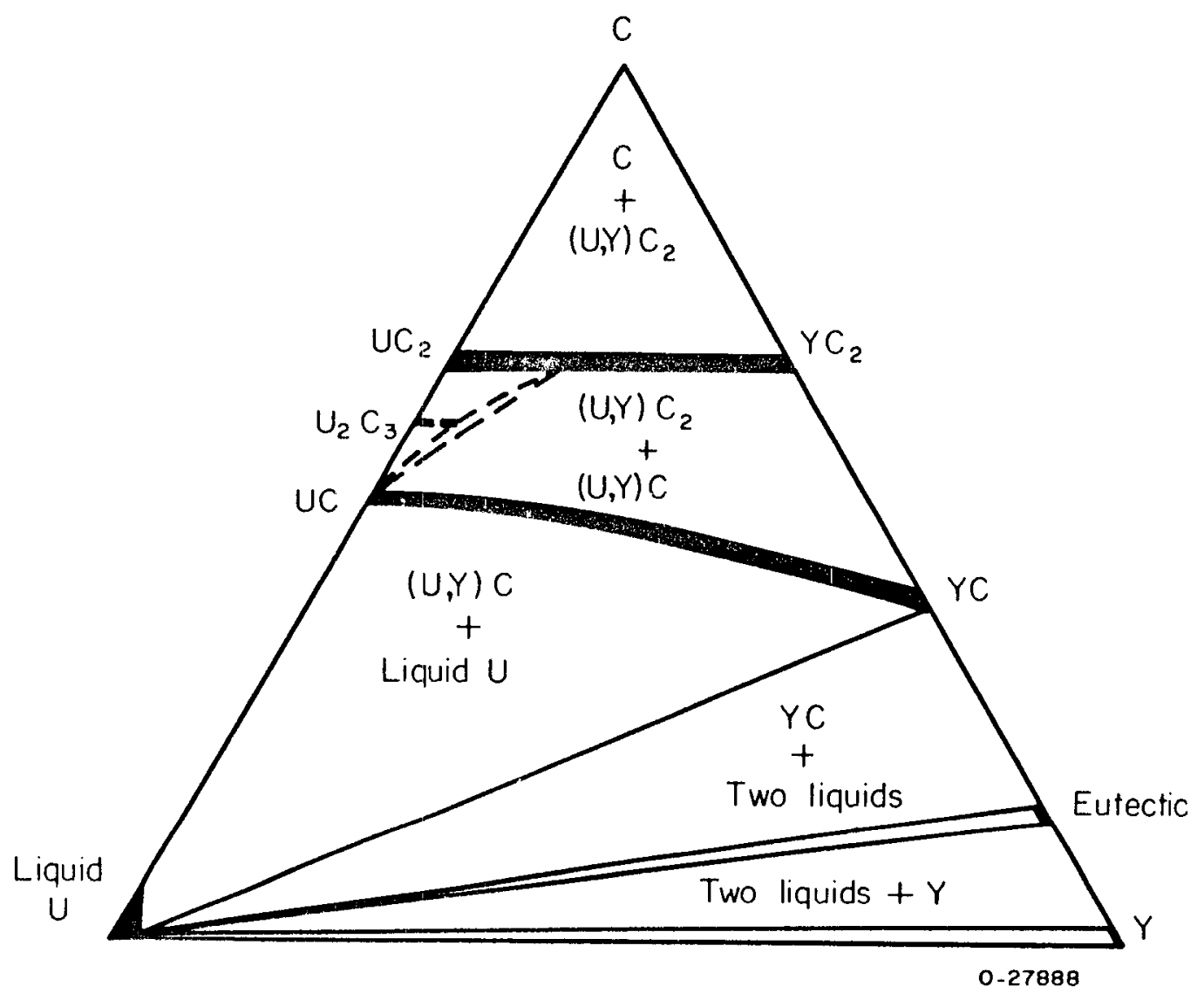

FIGURE 38. URANIUM-CARBON-YTTRIUM SYSTEM AT $1500 \mathrm{C}$ 


\section{REFERENCES}

(1) Rough, F. A., and Chubb, W., "A Evaluation of Data on Nuclear Carbides", BMI-1441 (May 31, 1960).

(2) Hansen, M. , and Anderko, K., Constitution of Binary Alloys, McGraw-Hill Book Company, Inc., New York (1958).

(3) Farr, J. D., LAMS-2545 (April 28, 1961). Confidential.

(4) Chubb, W., and Rough, F. A., Minutes of the Third Uranium Carbide Conference, Oak Ridge, 1960, TID-7603, pp. 12-24.

(5) Streets, F. G., Stobo, J. J., "The Uranium-Molybdenum-Carbon Equilibrium Diagram", J. Inst. Metals, 92, 171-174 (February 1964).

(6) Atomics International, unpublished data (February 1962).

(7) Rudy, E., Rudy, El., and Benesovsky, F., Symposium on the Thermodynamics of Nuclear Materials, Vienna, May 1962.

(8) Nowotny, H., Kieffer, R., and Benesovsky, F., "Preparation of UC and Its Relation to the Carbides of Refractory Transition Metals", Rev. mét., 55, 453-458 (May 1958).

(9) Rudy, E., Benesovsky, F., and Sedlatschek, K., "Investigation of the System: Nb-Mo-C", Monatsh. Chem., 92, 841-855 (1961).

(10) Clougherty, E. V., and Lothrop, K. H., "Monocarbide Phases of Molybdenum", Trans. AIME, to be published.

(11) Nowotny, H., Kieffer, R., Benesovsky, F., and Laube, E., "The Mixed Carbides in the Systems: U-Cr-C, U-Mo-C, and U-W-C," Monatsh. Chem., 89 692-700 (1958).

(12) Storms, E. K., and Krikorian, N. H., "The Niobium-Niobium Carbide System", J. Phys. Chem., 64, 1471-1477 (October 1960).

(13) Brownlee, L. D., "The Pseudo-Binary Systems of UC with ZrC, TaC, and NbC", J. Inst. Metals, 87, 58-61 (October 1958).

(14) Roof, R. B., and Lombardo, J. J., "A Pseudo-Binary in the U-Nb-C System", Trans. AIME, 212, 50 (February 1958).

(15) Ruby, E., and Benesovsky, F., "The Stability of $\mathrm{UC}_{2}$ and the Carbon-Stable Regions in the Systems of $\mathrm{UC}$ with $\mathrm{ZrC}, \mathrm{HFC}, \mathrm{NbC}$, and $\mathrm{TaC} "$, Monatsh. Chem. 94, 204-224 (1963).

(16) Yamamoto, K., Watanabe, K., and Sano, T., private communication (July 1963). 
(17) Grand, S., private communication (1960).

(18) Weinberg, A., and Yang, L., "Interdiffusion Between U ranium-Bearing Reactor Fuels and Refractory-Metal Thermionic Emitters", GA-3124 (May 4, 1962).

(19) Bowman, M. G., "Chemistry of Fuel Element Cathode Materials", TID-11439 (1960).

(20) Dolloff, R. T., and Sara, R. V., "Phase Equilibria of Selected Carbides", Progress Report No. 7, National Carbon Company, Parma, Ohio (August 1961).

(21) Newkirk, H. W., and Bates, J. L., "The Melting Points of Uranium Dioxide, Uranium Monocarbide, and Uranium Mononitrile", HW-59468 (March 4, 1959).

(22) "Progress in Carbide Fuels; Notes from the Second AEC Uranium Carbide Meeting, Held at Battelle Memorial Institute, March 22 and 23, 1960", Creagh, J.W.R., and Drell, I. L., "NASA Research Program on Compatibility of Uranium Monocarbide", TID-7589 (April 20, 1960), pp 30-33.

(23) Farr, J. D., LAMS-2505 (December 1960). Confidential.

(24) Childs, B. G., et al., "The Low Temperature Irradiation Behavior of Cast Uranium Carbide", Presented at Symposium on Radiation Damage, Venice, Italy, May 1962.

(25) Rudy, E., Rudy, E1., and Benesovsky, F., "Investigations of the Systems: Th-W-C and U-W-C", Monatsh. Chem., 93, 522-535 (1962).

(26) Spedding, F. H., Gschneider, K., and Daane, A. H., "The Crystal Structures of Some of the Rare Earth Carbides", J. Am. Chem. Soc., 80, 4499-4503 (1958).

(27) Samsonov, G. V., Makarenko, G. N., and Kosolapova, T. Ya., "Preparation and Properties of Yttrium Monocarbide", Zhur. Priklad. Khim., 34, 1444-1448 (1961).

(28) Spedding, F. H., "Rare Earths", Intern. Sci. Tech. 39-46 (April, 1962).

WC:DLK/dnm 